\title{
Blood and urine markers for ovarian cancer: A comprehensive review ${ }^{1}$
}

\author{
Kathryn L. Terry ${ }^{\mathrm{a}}$, Patrick M. Sluss ${ }^{\mathrm{b}}$, Steven J. Skates ${ }^{\mathrm{c}, \mathrm{d}}$, Samuel C. Mok ${ }^{\mathrm{d}}$, Bin Ye ${ }^{\mathrm{d}}$, \\ Allison F. Vitonis ${ }^{\mathrm{a}}$ and Daniel W. Cramer ${ }^{\mathrm{a}}$ \\ ${ }^{a}$ Ob-Gyn Center Epidemiology Center, Department of Obstetrics, Gynecology, and Reproductive Biology, Brigham \\ and Women's Hospital, Boston, MA, USA \\ ${ }^{\mathrm{b}}$ Reproductive Endocrinology Unit Laboratory, Department of Medicine, Massachusetts General Hospital, Boston, \\ MA, USA \\ ${ }^{\mathrm{c}}$ Biostatistics Center, Massachusetts General Hospital, Boston, MA, USA \\ ${ }^{\mathrm{d}}$ Laboratory of Gynecologic Oncology, Department of Obstetrics, Gynecology, and Reproductive Biology, Brigham \\ and Women's Hospital, Boston, MA, USA
}

\section{Introduction}

The obvious appeal of a strategy for the early detection of ovarian cancer is based upon the tendency for the disease to present at advanced stages associated with poor survival. If the diagnosis could be largely shifted to stage I associated with survival close to $90 \%$, then the overall mortality for this disease could be dramatically altered without any advances in therapy. Whether a screening strategy can be successfully implemented for ovarian cancer depends upon the natural history of the disease, especially the length of time ovarian cancer remains in a pre-clinical phase prior to stage I, and the ability to develop a convenient and suitably-performing screening test acceptable to the target population. Preclinical disease refers to a stage in a disease process before which the disease has produced symptoms, which lead an individual to seek diagnosis or treatment. In the case of cancers like cervix or colon, pre-clinical disease can be equated with well-characterized precursor lesions known to precede the invasive cancer. But, for ovarian cancer, precursor lesions are largely unknown

\footnotetext{
${ }^{1}$ Supported by NCI Early Detection Research Network Gran \#U01CA086381.
}

as is the length of time that the disease remains in a pre-clinical phase.

Despite this lack of understanding, the public health importance of ovarian cancer demands active investigation of approaches to screening. Although these approaches might include pelvic examination, sonography, or even cytologic approaches, this review will focus on blood or urine markers for ovarian cancers as methods most likely to be adaptable to screening both general and high-risk populations. Table 1 summarizes ovarian cancer markers for which sensitivity and specificity estimates were available or where mean levels of markers for cases and controls were available. Sensitivity, the proportion of all those with disease who are screen positive, and specificity, the proportion of all those without disease who are screen negative, are chosen as the key performance characteristics. Unlike related measures such as the predictive values of a positive or negative test, which depend upon the prevalence of the disease in the population, sensitivity and specificity are more stable test parameters. We have also attempted to organize markers by structural or functional characteristics in order that some generalizations about broader categories of markers may be possible, acknowledging that there may be disagreement about how best to categorize a particular marker. 


\section{Epithelial sialomucins}

The epithelial sialomucins are currently the most important group of markers for ovarian cancer. These are heavily glycosylated proteins with relatively high molecular weights and include the only approved marker for monitoring ovarian cancer, CA-125, also known as MUC16. Although these proteins are transmembrane in location, they can be found in the serum. Most of the markers included in this category have been identified through approaches in which human cancer cells are used as an antigenic stimulus in animals to raise antibodies, which can then efficiently detect the antigen in human serum. A review of Table 1 suggests that CA 125 remains the best-documented and bestperforming single marker among the epithelial sialomucins currently described $[2,6,47,48,54,63,91,94,98$, $101,102,108,112,116]$. Sensitivity estimates vary from as low as $27 \%$ in some studies for early-staged disease to better than $90 \%$ for late-staged disease. Sensitivity is also greater for serous and endometrioid ovarian tumors compared to mucinous or clear cell tumors.

CA 15-3 (MUC1) is a biomarker described for breast (and other cancers) but is also relevant to ovarian cancer. It appears to be expressed in ovarian cancer types similar to CA 125 with promising sensitivity and specificity estimates in limited studies [7,24,48,80,102]. The nomenclature on CA 15-3 is confusing with a number of other terms describing markers similar or identical to CA 15-3 including human milk fat globulin 1 and 2 (HMFG1/2), CASA, OSA, and several others. The remaining sialomucins listed in Table 1 are not serious candidates to replace CA 125 based upon usually poorer and certainly more limited sensitivity and specificity estimates. Rather these are better viewed as markers, which may prove complementary to CA 125 . Thus CA 50, CA 54-61, CA 195, and CA 19-9 all appear to have greater sensitivity for mucinous tumors [17,29, 47,88] while STN and TAG-72 have better sensitivity for clear cell tumors [31,54]. Combinations of markers involving the sialomucins are discussed in more detail in Section 12.

In general there are several limitations common to members of this family of markers. First, based on their molecular weight, urine would not be a good medium to use in screening for these markers. Secondly, the high molecular weight and differing glycosylation patterns (epitopes) combine to produce the diagnostic problem that different antibodies can be generated and contribute to a lack of consistency between assays using different antibodies [99]. Thirdly, these markers may be secreted by a variety of epithelial tumors including breast, colon, ovary and pancreas as well as normal adult epithelial tissue including that from the breast, gastrointestinal and genitourinary tracts. Finally, a number of benign conditions can be associated with elevation of these markers. In particular, CA125 can be elevated in early pregnancy and with endometriosis, fibroids, or infections of the genital tract [99]. These would, of course, affect the specificity of the test and the possibility of false positive results. One strategy, besides combining markers, to improve the specificity associated with use of these markers would be to use serial testing. Elevated but declining marker levels would indicate a transient condition associated with marker production. Elevated but stable levels might indicate chronic but benign conditions associated with marker production, while elevated and increasing levels are more likely indicative of cancer [87,112]. Another approach to improve specificity would be to combine the marker with an imaging test such as pelvic ultrasounda strategy found in a randomized trial in England to improve the median survival of screen detected cases [113].

\section{Proteases, inhibitors, and cleavage products}

Based on the number described, the proteases and related peptides may be the next most valuable group of markers for ovarian cancer. Within this group, the kallikreins, a family of serine proteases, have captured attention because of the importance of prostate-specific antigen (PSA) for detecting prostate cancer in men. PSA was originally discovered through techniques similar to those employed for the sialomucins in which crude or partially purified extracts of normal and cancerous prostate tissues were used to immunize rabbits [100]. Later, PSA was identified to be a member of the human kallikrein family prompting interest in other members of this group. The importance of this family of proteins to ovarian cancer has been subsequently demonstrated through techniques used to identify genes, which are over expressed in ovarian cancer cells. Indeed, the entire family of kallikreins map to a region on chromosome $19 \mathrm{q}$ shown to be amplified in ovarian cancers $[19,20,85,110]$.

Currently the best performing of these markers include kallikrein 6 (protease M) and kallikrein 10 with sensitivities reported between 47 and $75 \%$ and specificities between 90 and $100 \%$ [21,56]. Sensitivity was improved when kallikrein 10 was combined with CA 
Table 1

Potential ovarian cancer tumor markers with previously reported sensitivity and specificities

\begin{tabular}{|c|c|c|c|c|}
\hline Category/Marker & References & Sensitivity & Specificity & Comments \\
\hline \multicolumn{5}{|l|}{ Epithelial sialoтисіns } \\
\hline CA 125 (MUC 16) & $\begin{array}{l}\text { Adonkis } 1996^{\mathrm{a}}, \\
\text { Bast } 1983^{\mathrm{a}}, \\
\text { Inoue } 1992^{\mathrm{a}, \mathrm{b}}, \\
\text { Jacobs } 1992^{\mathrm{a}, \mathrm{b}}, \\
\text { Kudoh } 1999^{\mathrm{a}} \text {, } \\
\text { Molina } 1992^{\mathrm{a}}, \\
\text { Tholander } 1990^{\mathrm{a}, \mathrm{b}}, \\
\text { Tamakoshi } 1996, \\
\text { van Haaften-Day } 2001 \\
\text { Woolas } 1995^{\mathrm{a}}, \\
\text { Woolas } 1993^{\mathrm{a}}, \\
\text { Yin 2001, } \\
\text { Zurawski } 1990^{\mathrm{a}}\end{array}$ & $24-97 \%$ & $\begin{array}{l}71-100 \% \text {; } \\
62 \% \text { in subjects with other malig- } \\
\text { nancies; } \\
71-86 \% \text { in benign tumors; } \\
96 \% \text { in healthy controls }\end{array}$ & $\begin{array}{l}\text { Sensitivity by stage: } \\
\text { Stage I = 27-66\%, } \\
\text { Stage II = 65-100\%; } \\
\text { Stage III = 87-90\% } \\
\text { Stage IV = 94\% } \\
\text { Sensitivity by histology: } \\
\text { Serous: } 68-94.1 \% \\
\text { Mucinous: } 52-68 \% \\
\text { Endometrioid: } 92 \% \text {, } \\
\text { Clear cell: } 61 \% \text {; }\end{array}$ \\
\hline CA 15-3 (MUC-1) & $\begin{array}{l}\text { Bast } 1991^{\mathrm{a}} \text {, } \\
\text { Feng } 2002, \\
\text { Jacobs } 1992^{\mathrm{a}} \\
\text { Scambia } 1988^{\mathrm{a}} \\
\text { Woolas } 1995^{\mathrm{a}}\end{array}$ & $57-93 \%$ & $\begin{array}{l}80 \% \text { in women with benign ovarian } \\
\text { tumors; } \\
100 \% \text { in women with benign gyne- } \\
\text { cological conditions; } \\
87 \% \text { in women with pelvic mass; } \\
98 \% \text { in women with benign disease } \\
\text { and elevated CA } 125\end{array}$ & $\begin{array}{l}\text { Sensitivity by stage: } \\
\text { Stage I }=27 \% \text {, } \\
\text { Stage II }=79-87 \% \text {, } \\
\text { Stage III }=85-93 \% \\
\text { MUC-1 expression less common in mu- } \\
\text { cinous tumors, more common in serous, } \\
\text { endometrioid; } \\
\text { In combination with TAG } 72.3 \text { or CA } \\
125 \text {, specificity ranges from } 94-100 \% \text {; }\end{array}$ \\
\hline HMFG1/G2 & $\begin{array}{l}\text { Bast } 1991^{\mathrm{a}}, \\
\text { Dhokia } 1986^{\mathrm{b}}, \\
\text { Fisken } 1993^{\mathrm{b}}\end{array}$ & $50-65 \%$ & $\begin{array}{l}83-97 \% \text {; } \\
12-26 \% \text { in women with benign dis- } \\
\text { ease and elevated CA } 125\end{array}$ & $\begin{array}{l}\text { Sensitivity by stage: } \\
\text { Stage I: } 45 \% \text {, } \\
\text { Stage II } 54 \% \text {, } \\
\text { Stage III: } 61 \% \text {, } \\
\text { Stage IV: } 75 \% \text {; } \\
\text { Sensitivity by histology: } \\
\text { Serous: } 51-68 \% \\
\text { Mucinous: } 25 \% \\
\text { Clear cell: } 40-60 \% \\
\text { Endometrioid: } 58-75 \% \text {; } \\
\text { In combination with CA125, sensitivity } \\
=95 \% \text {, specificity }=93 \%\end{array}$ \\
\hline $\begin{array}{l}\text { Cancer- } \\
\text { associated serum anti- } \\
\text { gen (CASA) }\end{array}$ & $\begin{array}{l}\text { McGuckin } 1990^{\mathrm{a}, \mathrm{b}} \\
\text { Hogdall } 2000^{\mathrm{a}}\end{array}$ & $30-76 \%$ & $\begin{array}{l}98 \% \text { in benign tumors and normal } \\
\text { controls }\end{array}$ & $\begin{array}{l}\text { Sensitivity by stage: } \\
\text { Stage I/II: } 23 \% \\
\text { Stage III/IV: } 39 \%\end{array}$ \\
\hline CA 50 & Gadducci $1991^{\mathrm{a}}$ & $35 \%$ & $67 \%$ & $\begin{array}{l}\text { Sensitivity in non-mucinous }=26 \% \text {, } \\
\text { Sensitivity in mucinous }=88 \%\end{array}$ \\
\hline CA $54-61$ & $\begin{array}{l}\text { Suzuki 1990, } \\
\text { Woolas } 1995^{\text {a }}\end{array}$ & $52-60 \%$ & $88-95 \%$ & Sensitivity in mucinous $=78 \%$ \\
\hline $\begin{array}{l}\text { CA } 195 \text { (carbohydrate } \\
\text { antigen 195) }\end{array}$ & $\begin{array}{l}\text { de Bruijn 1993a, } \\
\text { Gadducci } 1991^{\mathrm{a}}\end{array}$ & $35-72 \%$ & $72-86 \%$ & $\begin{array}{l}\text { Sensitivity in mucinous }=72 \%, \\
\text { Sensitivity in non-mucinous }=35 \%\end{array}$ \\
\hline CA $19-9$ & $\begin{array}{l}\text { Engelen } 2000^{\mathrm{a}}, \\
\text { Inoue } 1992^{\mathrm{a}, \mathrm{b}}, \\
\text { Kudoh } 1999^{\mathrm{a}}, \\
\text { Molina } 1992^{\mathrm{a}}, \\
\text { Gadducci } 1991^{\mathrm{a}}, \\
\text { Tamakoshi } 1996, \\
\text { Woolas } 1995^{\mathrm{a}}\end{array}$ & $24-75 \%$ & $\begin{array}{l}59 \% \text { in benign tumors; } \\
52 \% \text { in subjects with other malig- } \\
\text { nancies; } \\
88 \% \text { in women with pelvic mass }\end{array}$ & $\begin{array}{l}\text { Sensitivity by stage: } \\
\text { Stage I }=33-62 \% \\
\text { Stage II }=10-60 \% \\
\text { Stage III }=35 \% \\
\text { Stage IV }=41 \% \\
\text { Sensitivity by histology: } \\
\text { Serous: } 40-52 \% \\
\text { Mucinous: } 45-80 \% \\
\text { Endometrioid: } 50-75 \% \\
\text { Clear cell: } 60.9 \%\end{array}$ \\
\hline MAM-6 & Hilkens 1986 & $78 \%$ & $\begin{array}{l}97 \% \text { in subjects with benign tumors } \\
\text { (all kinds) }\end{array}$ & $\begin{array}{l}\text { Mean level in ovarian cancer patients: } \\
43.2 \pm 64 \text { units } / \mathrm{ml}\end{array}$ \\
\hline $\mathrm{NB} / 70 \mathrm{~K}$ & $\begin{array}{l}\text { Bast } 1991^{\mathrm{a}}, \\
\text { Petru } 1990^{\mathrm{a}, \mathrm{b}} \\
\text { Knauf } 1988^{\mathrm{b}}\end{array}$ & $57-76 \%$ & $\begin{array}{l}74 \% \text {; } \\
38 \% \text { in women with benign disease } \\
\text { and elevated CA } 125\end{array}$ & $\begin{array}{l}45-50 \% \text { sensitivity in early stage } \\
\text { disease }\end{array}$ \\
\hline $\begin{array}{l}\text { Ovarian serum antigen } \\
\text { (OSA) }\end{array}$ & McGuckin $1990^{\mathrm{a}}$ & $82 \%$ & $95 \%$ & \\
\hline
\end{tabular}


Table 1, continued

\begin{tabular}{|c|c|c|c|c|}
\hline Category/Marker & References & Sensitivity & Specificity & Comments \\
\hline OVX1 & $\begin{array}{l}\text { Hogdall } 2000^{\mathrm{a}} \text {, } \\
\text { van Haaften-Day 2001, } \\
\text { Woolas } 1993^{\mathrm{a}} \text {, } \\
\text { Woolas } 1995^{\mathrm{a}} \text {, } \\
\text { Xu } 1993\end{array}$ & $9-70 \%$ & $\begin{array}{l}83-94 \% \\
86-93 \% \text { in benign, } \\
91-95 \% \text { healthy controls }\end{array}$ & $\begin{array}{l}\text { Sensitivity by stage: } \\
\text { Stage I: } 22 \% \text {, } \\
\text { Stage II: } 25 \% \text {, } \\
\text { Stage III: } 15 \% \text {, } \\
\text { Stage IV: } 18 \% \text {; } \\
\text { Sensitivity by histology: } \\
\text { Serous: } 70 \% \text {, } \\
\text { Mucinous: } 75 \% \text {, } \\
\text { Endometrioid: } 67 \% \text { Incombination } \\
\text { with CA } 125 \text { and MCSF, sensitivity = } \\
85 \% \text {, specificity }=83 \%\end{array}$ \\
\hline STN (sialyl TN) & $\begin{array}{l}\text { Inoue } 1990^{\mathrm{b}}, \\
\text { Inoue } 1992^{\mathrm{a}, \mathrm{b}}, \\
\text { Kudoh } 1999^{\mathrm{a}} \text {, }\end{array}$ & $44-50 \%$ & $\begin{array}{l}92 \% \text { in benign tumors; } \\
94 \% \text { in benign ovarian cysts; } \\
99 \% \text { in normal volunteers }\end{array}$ & $\begin{array}{l}\text { Sensitivity by stage: } \\
\text { Stage I: } 31-44 \% \text {, } \\
\text { Stage II: } 29-50 \% \\
\text { Stage III: } 69 \% \\
\text { Sensitivity by histology: } \\
\text { Serous: } 61.9 \% \\
\text { Mucinous: } 60.0 \% \text {, } \\
\text { Endometrioid: } 60.0 \% \\
\text { Clear cell: } 75.0 \%\end{array}$ \\
\hline $\begin{array}{l}\text { TAG-72 (tumor as- } \\
\text { sociated glycoprotein- } \\
\text { 72) (called CA72-4) }\end{array}$ & $\begin{array}{l}\text { Bast } 1991^{\mathrm{a}}, \\
\text { Fiella } 1999, \\
\text { Guadagni } 1994^{\mathrm{a}}, \\
\text { Jacobs } 1992^{\mathrm{a}, \mathrm{b}}, \\
\text { Negishi } 1993 \text {, } \\
\text { Nishida } 1995^{\mathrm{a}} \text {, } \\
\text { Woolas } 1995^{\mathrm{a}} \text {, } \\
\text { Zeimet } 1995\end{array}$ & $10-63 \%$ & $\begin{array}{l}73-99 \% \text {; } \\
94 \% \text { in women with benign disease } \\
\text { and elevated CA125; } \\
97 \% \text { in benign ovarian conditions, } \\
100 \% \text { in other benign gynecologic } \\
\text { conditions }\end{array}$ & $\begin{array}{l}\text { Sensitivity by stage: } \\
\text { Stage I-II: } 10 \% \\
\text { Stage III-IV: } 56 \% \\
\text { Sensitivity by histology: } \\
\text { Serous: } 59 \% \text {, } \\
\text { Mucinous: } 25 \% \text {, } \\
\text { Endometrioid: } 63 \% \text {, } \\
\text { May be more useful in clear cell tumors; } \\
\text { In combination with CA } 125 \text {, sensitivity } \\
=86 \% \text {, spec. = } 83 \% \text {; } \\
\text { In combination with TAG } 72.3 \text { or CA } \\
15-3 \text {, specificity ranges from } 94-100 \% \text {; }\end{array}$ \\
\hline \multicolumn{5}{|l|}{$\begin{array}{l}\text { Proteases and their } \\
\text { inhibitors }\end{array}$} \\
\hline $\begin{array}{l}\text { Kallikrein } 6 \text { (Protease } \\
\text { M) }\end{array}$ & $\begin{array}{l}\text { Diamandis } 2000^{\mathrm{b}}, \\
\text { Diamandis } 2003^{\mathrm{a}, \mathrm{b}}\end{array}$ & $47-66 \%$ & $\begin{array}{l}100 \% \text { in healthy men and women; } \\
90-95 \% \text { in healthy and benign } \\
\text { controls }\end{array}$ & $\begin{array}{l}\text { Sensitivity by stage: } \\
\text { Stage I: } 16 \% \\
\text { Stage II: } 27 \% \\
\text { Stage III: } 75 \% \\
\text { Stage IV: } 63 \% \\
\text { Sensitivity by histology: } \\
\text { Serous: } 68 \% \\
\text { Endometrioid } 33 \% \\
\text { Mucinous: } 9 \% \text {; } \\
\text { In combination with CA } 125: \text { sensitiv- } \\
\text { ity }=69 \% \text {, specificity }=95 \%\end{array}$ \\
\hline Kallikrein 10 & $\begin{array}{l}\text { Luo (Clin Cancer Res) } \\
2001 \text {, } \\
\text { Luo (Clinica Chimica } \\
\text { Acta) } 2001^{\mathrm{b}} \text {, } \\
\text { Luo } 2003^{\mathrm{a}} \text {, } \\
\text { Shvartsman 2003, }\end{array}$ & $54-78 \%$ & $90-100 \%$ & $\begin{array}{l}\text { Sensitivity by stage: } \\
\text { Stage I: } 6 \% \text {, } \\
\text { Stage II: } 18 \% \text {, } \\
\text { Stage III: } 52 \% \text {, } \\
\text { Stage IV: } 50 \% \\
\text { Sensitivity by histology: } \\
\text { Serous: } 47 \% \text {, } \\
\text { Endometrioid: } 13 \% \text {, } \\
\text { Mucinous: } 5 \% \\
\text { In combination with CA } 125 \text {, sens = } \\
73 \% \text {; } \\
\text { Sensitivity for stage I/II }=35 \% \text {; }\end{array}$ \\
\hline Kallikrein 11 & Diamandis 2002 & $50 \%$ & $\begin{array}{l}\text { In other cancers: } \\
100 \% \text { in lung and pancreatic can- } \\
\text { cers, } \\
79 \% \text { in colon cancer, } \\
95 \% \text { in thyroid cancer }\end{array}$ & \\
\hline
\end{tabular}


Table 1, continued

\begin{tabular}{|c|c|c|c|c|}
\hline Category/Marker & References & Sensitivity & Specificity & Comments \\
\hline $\begin{array}{l}\text { MMP-2 (matrix met- } \\
\text { alloproteinase 2) }\end{array}$ & Schmalfeldt 2001 & $66 \%$ & $100 \%$ & \\
\hline Prostasin & Mok $2001^{\mathrm{a}}$ & $51 \%$ & $94 \%$ & $\begin{array}{l}\text { In combination with CA125: } \\
\text { sensitivity }=92 \% \text {, specificity }=94 \%\end{array}$ \\
\hline Matriptase & Oberst $2002^{\mathrm{a}}$ & $72 \%$ & & $\begin{array}{l}\text { Sensitivity by stage: } \\
\text { Stage I: } 81 \% \text {, } \\
\text { Stage II: } 100 \% \text {, } \\
\text { Stage III: } 58 \% \text {; } \\
\text { Sensitivity by histology: } \\
\text { Serous: } 61 \% \text {, } \\
\text { Mucinous: } 75 \% \text {, } \\
\text { Endometrioid: } 82 \% \text {, } \\
\text { Clear cell: } 67 \%\end{array}$ \\
\hline Cathepsin $\mathrm{L}^{\mathrm{a}}$ & Nishida $1995^{\mathrm{a}}$ & $80 \%$ & $85 \%$ & \\
\hline Alpha-1-antitrypsin & Kawai 1989 & $79 \%$ & $\begin{array}{l}89 \% \text { in benign gynecologic condi- } \\
\text { tions, } \\
10 \% \text { in pregnant women, } \\
100 \% \text { in healthy women }\end{array}$ & \\
\hline $\begin{array}{l}\text { Thrombin- } \\
\text { antithrombin III, D- } \\
\text { dimer } \\
\text { Cytokines, targets and } \\
\text { acute phase reactants }\end{array}$ & den Ouden M 1998 & $90 \%$ & $94 \%$ in benign tumors & \\
\hline $\begin{array}{l}\text { Immunosuppressive } \\
\text { acidic protein }\end{array}$ & $\begin{array}{l}\text { Castelli } 1991^{\mathrm{a}, \mathrm{b}}, \\
\text { Lin } 1994^{\mathrm{a}}, \\
\text { Sawada } 1983^{\mathrm{a}, \mathrm{b}}, \\
\text { Shimzu } 1986, \\
\text { Yamashita } 1986\end{array}$ & 70.4-93\% & $\begin{array}{l}91-96 \% ; \\
67-75 \% \text { using benign tumors; } \\
96 \% \text { in normal women }\end{array}$ & $\begin{array}{l}\text { Sensitivity by stage: } \\
\text { Stage I: } 12-100 \\
\text { Stage II: } 28-100 \% \\
\text { Stage III: } 53-100 \\
\text { Stage IV: } 80 \% \\
\text { Sensitivity by histology: } \\
\text { Serous: } 75-83 \% \\
\text { Mucinous: } 100 \% \\
\text { Clear cell: } 83-100 \% \\
\text { Poorly differentiated: } 66.7-100 \% \\
\text { Papillary: } 100 \% \\
\text { Germ cell: } 71.4-100 \%\end{array}$ \\
\hline $\begin{array}{l}\text { MCSF (macrophage } \\
\text { coloy-stimulating } \\
\text { factor) }\end{array}$ & $\begin{array}{l}\text { Suzuki 1998 a, } \\
\text { van Haaften-Day 2001, } \\
\text { Woolas } 1993^{\mathrm{a}} \text {, } \\
\text { Woolas } 1995^{\mathrm{a}} \text {, } \\
\text { Xu } 1991\end{array}$ & $29-100 \%$ & $\begin{array}{l}76 \% \text { in women presenting with } \\
\text { pelvic mass; } \\
75-93 \% \text { in women with benign dis- } \\
\text { ease; } \\
92-98 \% \text { in healthy controls }\end{array}$ & $\begin{array}{l}\text { Sensitivity by stage: } \\
\text { Stage I: } 31-87 \% \\
\text { Stage II: } 63-75 \% \\
\text { Stage III: } 37 \% \text {, } \\
\text { Stage IV: } 41-100 \% \text {; } \\
\text { In combination with CA } 125 \text {, sensitivity } \\
=98 \% \text {; } \\
\text { In combination with CA } 125 \text { and } \\
\text { OVX1, sensitivity }=57-85 \% \text {, specifici- } \\
\text { ty }=58-83 \%\end{array}$ \\
\hline Interleukin 6 & $\begin{array}{l}\text { Tempfer (Gyn Onc) } \\
1997^{\mathrm{b}}\end{array}$ & & & $\begin{array}{l}\text { Mean levels of IL- } 6(\mathrm{pg} / \mathrm{ml}) \text { and range: } \\
\text { In normal controls }=0.5(0-2) \\
\text { In ovarian cancer }=56(0-2869)\end{array}$ \\
\hline $\begin{array}{l}\text { SIL-2Ra (soluable } \\
\text { interleukin-2 receptor } \\
\text { alpha) }\end{array}$ & $\begin{array}{l}\text { Hurteau } 1995^{\mathrm{a}, \mathrm{b}} \\
\text { Sedlaczek } 2002^{\mathrm{a}}\end{array}$ & $95 \%$ & $5-97 \%$ & $\begin{array}{l}\text { In combination with CA125, sensitivity } \\
=89-100 \% \text {, } \\
\text { spec }=27-91 \% \text {; } \\
92 \% \text { stage } \mathrm{I} / \mathrm{II} \text { had elevated sIL-2R or } \\
\text { CA } 125,67 \% \text { had elevations of both; } \\
\text { Sensitivity by histology: } \\
\text { Serous: } 85 \% \text {, } \\
\text { Endometrioid: } 75 \% \text {, } \\
\text { Mucinous: } 86 \% \text {, } \\
\text { Undifferentiated: } 73 \%\end{array}$ \\
\hline Alpha-Haptoglobin & $\begin{array}{l}\text { Ye (Clin Cancer Res) } \\
2003^{\mathrm{a}}\end{array}$ & $64 \%$ & $90 \%$ & $\begin{array}{l}\text { In combination with CA } 125,91 \% \text { sen- } \\
\text { sitivity and } 95 \% \text { specificity }\end{array}$ \\
\hline
\end{tabular}


Table 1, continued

\begin{tabular}{|c|c|c|c|c|}
\hline Category/Marker & References & Sensitivity & Specificity & Comments \\
\hline \multicolumn{5}{|l|}{$\begin{array}{l}\text { Hormones } \\
\text { and growth/inhibition } \\
\text { factors }\end{array}$} \\
\hline Activin A & Menon $2000^{\mathrm{a}, \mathrm{b}}$ & $48 \%$ & $15 \%$ & \\
\hline $\begin{array}{l}\text { Gonadotropin } \\
\text { fragments }\end{array}$ & $\begin{array}{l}\text { Cole (Can Res) } 1988^{a, b}, \\
\text { Cole (Gyn Onc) } 1988^{a}\end{array}$ & $73-83 \%$ & $92 \%$ & \\
\hline Inhibins $\mathrm{A}$ and $\mathrm{B}$ & $\begin{array}{l}\text { Frias } 1999^{\mathrm{a}, \mathrm{b}} \\
\text { Menon } 2000^{\mathrm{a}, \mathrm{b}} \\
\text { Robertson } 2002\end{array}$ & $15-59 \%$ & $95 \%$ & $\begin{array}{l}\text { Sensitivity by histology: } \\
\text { Serous: } 10-18 \% \text {, } \\
\text { Mucinous: } 72-84 \% \text {, } \\
\text { Endometrioid: } 31-54 \% \text {, } \\
\text { Clear cell: } 22-44 \% \\
\text { Undifferentiated: } 33 \% \\
\text { Granulosa cell: } 100 \% \\
\text { Sensitivity by stage: } \\
\text { Stage I/ II: } 14 \% \\
\text { Stage III/ IV: } 86 \% \\
\text { Note: Variation in sensitivity de- } \\
\text { pends on type of assay used to mea- } \\
\text { sure Inhibin }\end{array}$ \\
\hline $\begin{array}{l}\text { Mesothelin/ } \\
\text { megakaryocyte poten- } \\
\text { tiating factor (MPF) }\end{array}$ & Scholler 1999 & $77 \%$ & $\begin{array}{l}100 \% \text { in healthy controls and pa- } \\
\text { tients with non-neoplastic diseases }\end{array}$ & Stages III-IV can be detected \\
\hline $\begin{array}{l}\text { TGF-alpha } \\
\text { (transforming growth } \\
\text { factor) }\end{array}$ & Chien $1997^{\mathrm{a}}$ & $33-71 \%$ & $\begin{array}{l}89 \% \text { in healthy women, } \\
72 \% \text { in benign ovarian tumors }\end{array}$ & $\begin{array}{l}\text { Sensitivity by stage: } \\
\text { Stage I: } 60 \% \\
\text { Stage II: } 71 \% \\
\text { Stage III: } 63 \% \\
\text { Stage IV: } 50 \% \\
\text { Sensitivity varies by histology: } \\
\text { Serous: } 71 \% \text {, } \\
\text { Endometrioid: } 70 \% \text {, } \\
\text { Mucinous: } 33 \%\end{array}$ \\
\hline $\begin{array}{l}\text { P110 epidermal } \\
\text { growth } \\
\text { factor receptor }\end{array}$ & $\begin{array}{l}\text { Baron } 1999^{\mathrm{a}} \\
\text { Baron } 2003^{\mathrm{a}}\end{array}$ & $\begin{array}{l}56 \% \text {; } \\
73 \% \text { at ages } \\
20-40, \\
61 \% \text { at ages } \\
41-60 \text {, } \\
33 \% \text { at ages } \\
61-87\end{array}$ & $\begin{array}{l}94 \% \text { in healthy women of all ages; } \\
94 \% \text { at ages } 20-40, \\
94 \% \text { at ages } 41-60 \\
93 \% \text { at ages } 61-80\end{array}$ & $\begin{array}{l}\text { Sensitivity by stage: } \\
\text { Stage I/II: } 34 \% \\
\text { Stage III/IV: } 61 \% \text {; } \\
\text { Median levels (fmol/ml): } \\
\text { Healthy women: } 7177 \text {, range ( } 114- \\
31,465 \text { ) } \\
\text { Ovarian cancer: } 463 \text {, range (unde- } \\
\text { tectable - } 82,436 \text { ) }\end{array}$ \\
\hline ErbB-2 (HER 2-Neu) & $\begin{array}{l}\text { Hellstrom } 2001^{\mathrm{a}}, \\
\text { van Haaften-Day } 1996\end{array}$ & $25-50 \%$ & $83 \%$ & $\begin{array}{l}\text { Sensitivity by stage: } \\
\text { Stage I/II: }<25 \% \text {, } \\
\text { Stage III/IV: } 100 \% \text {; } \\
\text { In combination with EGFR, sensi- } \\
\text { tivity }=81 \% \text { (and } 59 \% \text { in borderline } \\
\text { tumors), specificity }=48 \%\end{array}$ \\
\hline \multicolumn{5}{|l|}{ Cytokeratins } \\
\hline $\begin{array}{l}\text { TPA (tissue polypep- } \\
\text { tide antigen) }\end{array}$ & $\begin{array}{l}\text { Inoue } 1992^{\mathrm{a}, \mathrm{b}} \text {, } \\
\text { Kudoh } 1999^{\mathrm{a}} \text {, } \\
\text { Sedlaczek } 2002^{\mathrm{a}}, \\
\text { Toftager-Larsen } 1992^{\mathrm{a}}, \\
\text { Tholander } 1990^{\mathrm{a}, \mathrm{b}}\end{array}$ & $25-83.3 \%$ & $54.5-96 \%$ in benign tumors & $\begin{array}{l}\text { In combination with CA } 125 \\
\text { sens }=79.6-92.6 \% \text {, } \\
\text { spec }=50-72.7 \% \text { (both positive), } \\
\text { sens }=59.3-64.8 \% \\
\text { spec }=88.6-97.7 \% \\
\text { Sensitivity by stage: } \\
\text { Stage I: } 50 \% \\
\text { Stage II: } 78 \% \\
\text { Sensitivity by histology: } \\
\text { Serous: } 60-76 \% \\
\text { Endometrioid: } 30-81 \% \\
\text { Mucinous: } 35-86 \% \\
\text { Undifferentiated: } 82 \% \\
\end{array}$ \\
\hline
\end{tabular}


Table 1, continued

\begin{tabular}{|c|c|c|c|c|}
\hline Category/Marker & References & Sensitivity & Specificity & Comments \\
\hline M3/M21 & $\begin{array}{l}\text { Hefler 1998, } \\
\text { Tempfer (BJC) 1997a,b }\end{array}$ & $57-78 \%$ & $85-98 \%$ & $\begin{array}{l}\text { Ovarian cancer patients with } \\
\text { M3/M21 levels }<45 \text { U 1-1 survive } \\
\text { significantly longer than those with } \\
\text { levels }>45 \text { U 1-1; } \\
\text { Mean serum levels (U/I) of M3/M21 } \\
\text { and range: } \\
\text { In healthy controls: } 25.2(7.7-5.1) \\
\text { In ovarian cancer: } 52.4(0.1-4,595)\end{array}$ \\
\hline \multicolumn{5}{|l|}{ Lipo-proteins } \\
\hline $\begin{array}{l}\text { LPA (lysophospha- } \\
\text { tidic acid) }\end{array}$ & Xu 1998 & $90-97.9 \%$ & $89.6 \%$ & $\begin{array}{l}\text { Sensitivity by stage: } \\
\text { Stage I: } 90 \% \\
\text { Stage II-IV: } 100 \% \\
\text { Mean LPA level }\left({ }^{\mathrm{b}} \mathrm{mol} / \mathrm{L}\right) \text { and stan- } \\
\text { dard error: } \\
\text { In healthy controls }=0.6 \pm 0.19 \\
\text { In ovarian cancer }=8.6 \pm 1.45\end{array}$ \\
\hline $\begin{array}{l}\text { LSA (lipid-assocaited } \\
\text { sialic acid) }\end{array}$ & Petru 1990 & $79 \%$ & $63 \%$ & \\
\hline Apolipoprotein (a) & Kuesel 1992a & $81-89 \%$ & $66-77 \%$ & $\begin{array}{l}\text { Sensitivity by stage: } \\
\text { Stage I/II: } 84 \% \\
\text { Stage III/IV: } 89 \%\end{array}$ \\
\hline \multicolumn{5}{|l|}{ Oncofetal proteins } \\
\hline CEA & $\begin{array}{l}\text { Engelen } 2000^{\mathrm{a}} \text {, } \\
\text { Inoue } 1992^{\mathrm{a}, \mathrm{b}} \text {, } \\
\text { Kudoh } 1999^{\mathrm{a}} \text {, } \\
\text { Roman } 1998^{\mathrm{a}} \\
\text { Tholander } 1990^{\mathrm{a}, \mathrm{b}} \text {, } \\
\text { Tamakoshi } 1996 \text {, }\end{array}$ & $9-29 \%$ & $\begin{array}{l}87-97 \% \text { in women with benign tu- } \\
\text { mors } \\
65 \% \text { in women with ovarian cysts }\end{array}$ & $\begin{array}{l}\text { CEA in combination w/ CA } 125 \text { : } \\
\text { Sensitivity }=87-94 \% \\
\text { Specificity }=80-87 \% \\
\text { Sensitivity by histology: } \\
\text { Serous: } 0-13.8 \% \\
\text { Mucinous: } 33-80 \% \text {, } \\
\text { Endometrioid: } 0-20 \% \\
\text { Clear cell = } 8.7 \% \text {; } \\
\text { In borderline tumors, sensitivity = } \\
9 \%\end{array}$ \\
\hline $\begin{array}{l}\text { PLAP (placental-like } \\
\text { alkaline phosphatase) }\end{array}$ & $\begin{array}{l}\text { Ind } 1997^{\mathrm{a}} \text {, } \\
\text { Nozawa } 1990, \\
\text { Tholander } 1990^{\mathrm{a}, \mathrm{b}}, \\
\text { Toftager-Larsen } 1992^{\mathrm{a}}\end{array}$ & $25-58 \%$ & $\begin{array}{l}77-100 \% \text {; } \\
100 \% \text { in healthy women, } \\
\text { In women with benign tumors = } \\
68-94 \%\end{array}$ & $\begin{array}{l}\text { Sensitivity by stage: } \\
\text { Stage I: } 25-50 \% \text {, } \\
\text { Stage II: } 42 \% \\
\text { Stage III: } 47 \% \\
\text { Stage IV: } 58 \% \text {; } \\
\text { Incombination with CA } 125 \\
\text { (at least one positive), } \\
\text { sens }=78-83 \% \\
\text { spec }=57-71 \% \\
\text { (both tests positive), } \\
\text { sens }=30-43 \% \\
\text { spec }=98\end{array}$ \\
\hline \multicolumn{5}{|l|}{ Auto-antibodies } \\
\hline P53 & Gadducci $1996^{\mathrm{a}}$ & $33 \%$ & $\begin{array}{l}93 \% \text { in women with endometrial } \\
\text { cancer }\end{array}$ & $\begin{array}{l}\text { Sensitivity by stage: } \\
\text { Stage I/II: } 22 \% \text {, } \\
\text { Stage III: } 31 \% \text {, } \\
\text { Stage IV: } 50 \%\end{array}$ \\
\hline Ep-Cam & $\operatorname{Kim} 2003^{a}$ & $73 \%$ & $\begin{array}{l}81 \% \text { in normal controls, } \\
77 \% \text { in benign ovarian disease }\end{array}$ & $\begin{array}{l}\text { Mean auto-antibody levels: } \\
\text { Normal controls }=0.09 \text { (range } 0.05, \\
0.13 \text { ) } \\
\text { Benign disease }=0.10 \text { (range } 0.06, \\
0.15 \text { ) } \\
\text { Ovarian cancer }=0.13 \text { (range } 0.08, \\
0.20 \text { ) }\end{array}$ \\
\hline \multicolumn{5}{|r|}{ 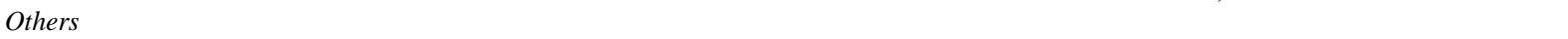 } \\
\hline Osteopontin & $\operatorname{Kim} 2002^{\mathrm{a}}$ & $80-85 \%$ & $80 \%$ & $\begin{array}{l}\text { Sensitivity by stage: } \\
\text { Stage I/II: } 80 \% \text {, } \\
\text { Stage III/IV: } 85 \% \\
\text { Mean level (ng/mL) and } 95 \% \text { CI: }\end{array}$ \\
\hline
\end{tabular}


Table 1, continued

\begin{tabular}{|c|c|c|c|c|}
\hline Category/Marker & References & Sensitivity & Specificity & Comments \\
\hline ALF (a-L-fucosidase) & $\begin{array}{l}\text { Abdel-Aleem } 1996^{\mathrm{a}} \text {, } \\
\text { Beattie } 1993\end{array}$ & $89 \%$ & $98 \%$ & $\begin{array}{l}\text { In healthy: } 147(8-641) \\
\text { In benign: } 254.4(3-641) \\
\text { In ovarian cancer: } 487(315-751) \\
\text { Mean ALF level }(\mathrm{IU} / \mathrm{ml}) \text { and stan- } \\
\text { dard deviation: } \\
\text { In healthy controls }=114 \pm 56 \text {, } \\
\text { In familial cases }=159 \pm 50, \\
\text { In sporadic cases }=124 \pm 54\end{array}$ \\
\hline Galactosyltranserase & $\begin{array}{l}\text { Udagawa } 1998^{\mathrm{b}} \text {, } \\
\text { Sichel } 1994\end{array}$ & $46 \%$ & $5 \%$ in benign ovarian tumors & $\begin{array}{l}\text { Sensitivity by histology: } \\
\text { Serous: } 56 \% \text {, }\end{array}$ \\
\hline LDH (lactate dehydrogenase) & $\begin{array}{l}\text { Kudoh } 1999^{\mathrm{a}} \\
\text { Schneider } 1997^{\mathrm{a}}\end{array}$ & $60-87 \%$ & $93 \%$ & $\begin{array}{l}\text { Endometrioid: } 50 \% \text {; } \\
\text { Sensitivity by histology: } \\
\text { Serous: } 57.1 \% \\
\text { Mucinous: } 33 \% \text {, } \\
\text { Endometrioid: } 50 \% \text {, } \\
\text { Clear cell: } 35 \% \text {; } \\
\text { Sensitivity in peritoneal fluid }(87 \%) \\
\text { is higher than in serum }(60 \%)\end{array}$ \\
\hline Tetranectin (TN) & Hogdall $2000^{a}$ & $17 \%$ & $94 \%$ in benign tumors & $\begin{array}{l}\text { Sensitivity by stage: } \\
\text { Stage I/II: } 4 \% \\
\text { Stage III/IV: } 35 \%\end{array}$ \\
\hline EDN (RNAaseA) & Ye (AACR) $2003^{\mathrm{a}}$ & $70-75 \%$ & $\begin{array}{l}80-94 \% \\
80 \% \text { for all subtypes, } \\
94 \% \text { for non-mucinous }\end{array}$ & $\begin{array}{l}\text { Sensitivity by stage: } \\
\text { Stage I/II: } 71 \% \text {, } \\
\text { Stage III/IV: } 75 \%\end{array}$ \\
\hline $\begin{array}{l}\text { Protein patterns } \\
\text { Cluster pattern algorithm }\end{array}$ & Petricoin $2002^{a}$ & $100 \%$ & $95 \%$ & \\
\hline
\end{tabular}

${ }^{\mathrm{a}}$ Indicates that pre-operative samples were used in the study.

${ }^{\mathrm{b}}$ Indicates that $\mathrm{CV}$ is available in the study.

125 [58]. It is not known whether combining several kallikreins will improve sensitivity and specificity, but this seems unlikely since they appear to be upregulated as group based on their tight genetic clustering. Prostasin is another serine protease, whose gene was discovered to be upregulated in ovarian cancer. When combined with CA 125 , its sensitivity to detect ovarian cancer was improved from $51 \%$ to $92 \%$ with a combined specificity of $94 \%$, similar to what was observed for kallikrein 10 [62].

The matrix metalloproteinases (MMP's) are another family of proteases that may be useful in ovarian cancer screening or prognosis. Unlike the kallikreins, genes for the MMP's are not clustered in the same chromosomal region. MMP-2 was reported to have $66 \%$ sensitivity and $100 \%$ specificity in a study that needs confirmation [83]. Other proteases described for ovarian cancer include urokinase-type plaminogen activator [97], matriptase [70], and thrombin [16]. Cathepsin L is a cysteine protease. Its level in the serum was found to be significantly elevated in ovarian cancer but no sensitivity estimate was provided [68]. The same paper described a lower false positive rate for this marker compared to CA 125 or CA 72-4 but null correlations suggesting it might be complementary to these markers.
For several of the proteases, their complementary inhibitors have been identified and may also be useful for ovarian cancer screening. Matriptase and its inhibitor hepatocyte growth factor activator inhibitor 1, [70] and urokinase and its inhibitor, plasminogen activator inhibitor type I [97], are examples of complementary pairs. Another protease inhibitor, HE4 was identified through gene upregulation studies and may prove useful for ovarian cancer screening [37]. Its complementary protease has apparently not been identified. Finally, thrombin, its inhibitor, anti-thrombin III, as well as a degradation product D-Dimer are examples of a triad of protease, inhibitor, and degradation product which may all be applicable for ovarian cancer screening [16] and provide a useful paradigm for research on other sets of proteases, inhibitors, and cleavage products. Indeed, cleavage products of proteases may prove to be a large and important group of markers for ovarian and other types of cancers. It is very likely that many of the low molecular weight "peaks" being identified through mass spectrometry (see Proteomic Patterns below) represent cleavage products of unidentified proteases.

Based on their biochemical role, it would seem likely that the proteases would be active in invasion and metastasis, and these markers do appear to have higher sensitivity for advanced stages of disease. A potential 
advantage of this category of markers based on their lower molecular weight is that urine might be a useful medium for screening. Indeed the MMPs have been found in urine for a number of cancers [66].

\section{Cytokines, targets, and acute phase reactants}

Arguably next in importance for ovarian cancer screening are the cytokines, which may prove to have good sensitivity for ovarian cancer, although it seems likely that their specificity may suffer from levels being elevated with other types of cancers as well as inflammatory conditions. Perhaps the best-known marker for ovarian cancer in this category is macrophage colony stimulating factor (MCSF), which was reported to have a sensitivity of 75 to $100 \%$ even for early stage disease and specificity of $92 \%$ to $98 \%$ in healthy controls [98,102,103]. Tumor necrosis factor (TNF)alpha is a cytokine that inhibits growth by increasing apoptosis. Consequently, one might expect its levels to be reduced in individuals with cancer. However, investigators reported no difference in TNF-alpha levels between individuals with ovarian cancer and those with benign tumors [75]. Yet, a chemical relative, TNFrelated apoptosis-inducing ligand was found to have a ten fold increase in ovarian cancer compared to normal ovarian epithelium, suggesting that increased levels may indicate the presence of ovarian cancer [55]. Interleukin (IL) 6 levels were significantly increased in serum and peritoneal fluid in ovarian cancer and correlated with stage of disease, although no sensitivity and specificity estimates provided [65,92]. Additional markers we include in this category are the soluble form of the IL receptors and acute phase reactant proteins. Soluble IL 2 receptor alpha had a sensitivity of $95 \%$ but very poor specificity improved by combining the marker with CA 125 [44]. The acute phase reactant protein alpha haptoglobin has also been identified as a potential marker for ovarian cancer. Interestingly, intact haptoglobin was identified years previously as a screening marker with modest sensitivity and specificity for multiple cancers. The fragment of haptoglobin alpha was rediscovered through mass spectrometry and found to have improved sensitivity and specificity when combined with CA-125. Finally, C-reactive protein levels were reported to be $\geqslant 50 \mathrm{mg} / \mathrm{l}$ in $20 \%$ stage I/II and $30 \%$ of stage III/IV ovarian cancers and to be associated with poorer survival [53].

\section{Hormones, growth/inhibition factors}

Based upon their role in normal ovarian physiology, epithelial tissue physiology, or tumor physiology, it would seem that a variety of hormones and growth or inhibition factors might be of value for ovarian cancer. However, few are of proven value for epithelial ovarian cancer screening, although several have been useful in immunohistochemical studies that correlate tumor staining properties with prognosis. As a key factor in ovarian physiology, the gonadotropins have been an important focus in animal studies but their measurement in serum does not appear useful in ovarian cancer screening. However, there has been some interest in urinary "gonadotropin fragments" with sensitivity ranging from 73 to $83 \%$ and specificity about $92 \%$ [15]. The inhibins are also key players in ovarian physiology and are representatives of a large group of proteins known as the transforming growth factor (TGF) beta superfamily, many of which have tumor suppressor or promoter functions. Although the inhibins have not shown particular value in the detection of epithelial ovarian cancer, they may prove useful for the diagnosis of granulosa cell tumors $[11,76]$. Serum TGF-alpha has also been examined for ovarian cancer with sensitivity estimates of $60-70 \%$ for early stage disease and specificity estimates of $89 \%$ for healthy controls [13]. Perhaps the current best performing marker in the growth factor category is Mesothelin, which was identified in gene upregulation studies, with a sensitivity of $77 \%$ (mostly late stage disease) and specificity of 100\% [82]. In addition to these growth or inhibition factors, soluble forms of their receptors have also been studied as potential markers. The epidermal growth factor receptor, called p110, has good specificity at $94 \%$ in healthy controls, but its sensitivity declines with age. At ages $20-40$, the p110 sensitivity is $73 \%$, but it declines to $33 \%$ in older women [4].

Several markers in this family have been used in histochemical staining of tumors and might correlate with prognosis. Epidermal growth factor assessed by immunohistochemical staining of tumors was found to be only marginally predictive of ovarian cancer [72]; and no association between the EGF receptor and stage of disease was found [98]. Other tumor markers of potential interest for "typing" tumors based on their immunohistochemistry include p53 and HER 2 neu. The reported proportion of epithelial ovarian cancers that express p53 varies widely, ranging from 3 to almost $50 \%[59,78,98]$. P53 expression is much lower at early stage than late stage disease [59,78]. P53 expression 
also varies by histology with the highest proportion of p53 positive cases in the invasive serous group and the lowest in the mucinous group [78]. P53 expression is virtually absent borderline tumors, and no benign tumors stained positively for p53 expression [98]. HER2 neu is found in less than $25 \%$ of newly diagnosed ovarian cancers [36].

\section{Cytokeratins}

Further related to epithelial cell biology, the cytokeratins are a group of intermediate filament proteins that compose the cytoskeleton of epithelial cells. Although individual cytokeratins may be relevant to ovarian cancer, more frequently mixtures of them have been studied. The best known of these is tissue (specific) polypeptide antigens (TPA or TPS). A wide range of sensitivities and specificities has been reported but the best performance has been achieved when this marker is combined with CA 125 . In several studies, the reported sensitivity was between 79 and $93 \%$ and the reported specificity between 89 and $98 \%$ [47,84,94,95]. A mixture of two cytokeratins, known as M3/M21 has also been studied as a marker for ovarian cancer with poorer sensitivity but better specificity than TPA [35, 92].

\section{Lipids and lipo-proteins}

There was considerable excitement and interest in a lipid marker for ovarian cancer, lysophosphatidic acid (LPA) based on a 1998 report [114], which described a sensitivity of $97.9 \%$ and specificity of $89.6 \%$. The requirement of this assay for quickly processed and frozen plasma appears to have affected enthusiasm for this marker although a search for more stable forms is underway. Apolipoprotein A has a reasonable sensitivity, ranging from 81-89\%, but poor specificity (23$34 \%$ ). Both sensitivity and specificity varied by age. At ages less than 49, sensitivity is high but specificity is poor. For ages greater or equal to 49 , sensitivity decreases but specificity increases [115]. Not shown in Table 1 since serum levels have not been reported are two other apolioproteins, apolipoprotiens $\mathrm{E}$ and $\mathrm{J}$ (also known as clusterin). Both of these were found to be highly upregulated in large scale serial analysis of gene expression (SAGE) and may prove of value in ovarian cancer screening or prognosis [43].

\section{Oncofetal proteins}

Of the traditional oncofetal proteins, carcinogenic embroyonic antigen (CEA) and alpha-fetal protein (AFP), CEA has been the topic of several studies while AFP appears to have diagnostic value only for the germ cell tumors. CEA had very little sensitivity by itself for detecting epithelial ovarian cancer. Although not traditionally considered an oncofetal protein, placenta like alkaline phosphatsase (PLAP), was identified decades ago by similar techniques used to identify CEA and AFP; i.e. studies to identify antigens common to cancer and fetal tissue. PLAP has been the topic of several studies, but like CEA appears to have reasonable performance in screening only when combine with CA 125 with a sensitivity of $93 \%$ and a specificity of $83 \%$ [94].

\section{Auto-antibodies}

The neoplastic process is associated with the entry of a variety of cancer proteins into the circulation that may lead to auto-antibody production. Although a very small number of screening markers currently fit into this category, we think it is important to include this as a distinct and potentially important group of biomarkers for ovarian cancer. Antibodies to p53 have been evaluated but showed poor sensitivity and appear to be of little screening value [30,41]. Rare cases of cerebellar degeneration in association with ovarian cancer have been described and appear to represent a paraneoplastic response to auto-antibodies that react with Purkinje cells [38]. Based on the fact that the cerebellar symptoms often preceded a clinical diagnosis of ovarian cancer, it seems reasonable to speculate that autoantibody formation could precede other clinical symptoms and thus be a potentially good marker for early stage disease [64]. Currently, the only marker studied for its potential as a screening tool is based upon autoantibodies directed against the epithelial cell adhesion molecule (Ep-CAM). This study compared Ep-CAM auto-antibody levels in the sera of 26 healthy controls, 26 women with benign disease, and 26 ovarian cancer patients. Investigators report that the Ep-CAM autoantibody screening showed a sensitivity of $73.1 \%$ and a specificity of $80.8 \%$ (95\% CI $=65.7$ to 95.9$)$, while CA125 alone in the same set of sample provided a sensitivity of $86.5 \%$ and a specificity of $88.5 \%$. The combination of Ep-CAM auto-antibody and CA125 gave a sensitivity of $90.4 \%$ and specificity of $92.3 \%$ [51]. 


\section{Other markers}

A variety of other markers not easily classified have been studied in ovarian cancer screening or prognosis. These include several markers identified through biochemical assays, multifunction proteins, and general measures of the degree of gycosylation. Enzymatic tests of potential value for ovarian cancer include alpha-fucosidase, galacotsyltransferase, and LDH [1,8, $54,81,86,96]$. RNAase A is a biomarker initially assessed for other cancers but found to be elevated in the urine of ovarian cancer patients identified through mass spectrometric approaches [107]. Osteopontin is a multifunction protein identified through gene upregulation studies and found to have higher mean levels in sera from ovarian cancer subjects compared to that from normal women or those with benign disease [50]. Lipid - associated sialic acid provides a more global measure of sialic acid, an amino carbohydrate, that is an important component of tumor glycoproteins and does correlate with advanced ovarian and other types of cancer. However, this test lacks specificity since it may be associated with non-neoplastic conditions as well.

\section{Proteomic patterns}

We conclude our review of markers for ovarian cancer with the recent innovative approach of using mass spectrograph patterns of proteins or small molecules as the screening test [73]. This potential advance has been permitted by high throughput mass spectrometry combined with sophisticated biostatistical approaches to identify patterns in the output. When presented with a test set of sera (or other biologic specimens), the algorithm was able to find a pattern that distinguished cancer cases from controls with near perfect accuracy and that was reproducible when presented with specimens from a comparable set of cases and controls. However, as was illustrated in the article describing this approach, when presented with a novel set of alternate controls, the algorithm assigned a "new pattern" for most of these controls. Thus, the transferability of the algorithm to novel specimens as well as the ability to standardize the output from mass spectrometry appear to be current obstacles for adapting this approach to clinical care. Other studies using mass spectrometry have attempted to identify components of the predictive patterns - most of which appear to be in the low molecular weight range, which may make this an ideal tool for the discovery of urinary markers for ovarian cancer.

\section{Combinations of markers}

In reviewing Table 1 it is apparent that sensitivities and specificities were often provided for combinations of 2 or more markers (usually with CA 125 as one of these). Table 2 highlights these combinations for easier comparison. Some of the better performing combinations of markers include CA 125 and HMFG1/G2 with a sensitivity of $93 \%$ and a specificity of $93 \%$ [18] as well as CA 125 and CEA with a sensitivity of $93 \%$ and a specificity of 93\% [94]. CA 125 with TAG72 and CA15-3 increase the specificity to $95 \%$ but sacrifice sensitivity [7]. We should note here that the traditional approach to combining multiple markers in most of these studies has been to use fixed cutoffs for each marker. Figure 1 illustrates the limitations of this approach in a simple two marker example using actual data on haptoglobin-alpha and CA 125 from the paper by Ye [106]. Using fixed cutoffs for both markers and declaring a positive screen to occur when either cutoff is exceeded and a negative screen to occur only when both values are below the cutoff, subjects within the box are declared negative and subjects outside the box are declared positive. This rule leads to 6 cases falsely declared negative and 18 controls falsely declared positive.

However a linear or logistic function of the two parameters, represented by the diagonal line, declares a negative screen to occur below the diagonal and a positive screen to occur above the diagonal. This rule leads to 8 cases falsely declared negative and 10 controls falsely declared positive; i.e. a substantial improvement in specificity with only a modest decrease in sensitivity. The problem becomes more complex when the distributions for the markers are not normal or when more than two markers are being examined. Logistic regression models for more than two variables or mixtures of multivariate normal distributions have been suggested. While a full discussion goes beyond the scope of this paper, the topic is considered in more detail elsewhere $[33,87]$.

\section{Discussion}

To some extent, the markers identified in Table 1 reflect the dual evolution of cancer model systems and available biologic tools. Some of the earliest models relied upon experimentally-induced tumors in animals and used relatively simple gel and immune based tools to identify cancer antigens not found in adult tissue but 
Table 2

Sensitivity and specificity of markers combinations

\begin{tabular}{|c|c|c|c|c|}
\hline Marker combinations & References & Sensitivity $(\%)$ & Specificity $(\%)$ & Method of analysis \\
\hline CA 125, TPS, sIL-2Ra & Sedlaczek 2002 & 100 & 72 & Cutoffs \\
\hline CA 125, HMFG1/G2 & Dhokia 1986 & 95 & 93 & Cutoffs \\
\hline CA 125, CEA & Tholander 1990 & 93 & 83 & Cutoffs \\
\hline CA 125 , Haptaglobin alpha & Ye 2003 & 91 & 95 & Logistic Regression \\
\hline CA 125, Ep-CAM & Kim 2003 & 90 & 92 & Logistic Regression \\
\hline CA 125, TN, OVX1, CASA & Hogdall 2000 & 89 & 66 & Cutoffs \\
\hline CA 125, TPA, PLAP & Toftager-Larsen 1992 & 85 & 59 & Cutoffs \\
\hline CA 125, OVX1, MCSF & Van Haaften-Day 2001 & 85 & 83 & Cutoffs \\
\hline CA 125, IAP & Castelli 1991 & 85 & 95 & Cutoffs \\
\hline CA 125, OVX1, LASA, CA15-3, CA72-4 & Woolas 1995 & 83 & 84 & Logistic Regression \\
\hline CA 125, TAG72, CA15-3 & Bast 1991 & 79 & 95 & Cutoffs \\
\hline CA 125, hK10 & Luo 2003 & 73 & 90 & Cutoffs \\
\hline CA 125, CEA, STN & Inoue 1992 & 71 & 76 & Cutoffs \\
\hline CA 125, MCSF, OVX1 & Woolas 1993 & 67 & 89 & Cutoffs \\
\hline
\end{tabular}

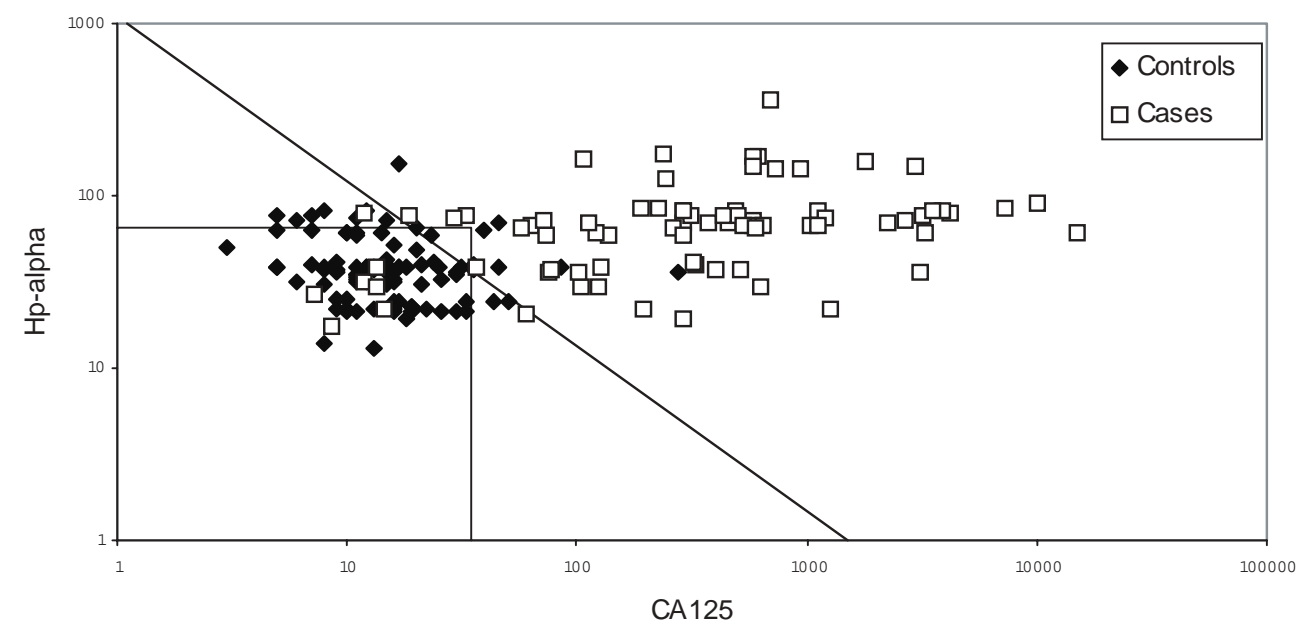

Fig. 1. Fixed cutoffs versus linear models in a study of two markers.

often found in fetal tissue from the same organ in the animal model. These led to identification of oncofetal proteins like CEA as some of the earliest cancer biomarkers. Since many early diagnostic tests in the general medical clinic relied upon enzymatic tests, it is not surprising that many of these found a role as early cancer diagnostic tests, including lactate dehydrogenase and acid phosphatase. With the evolution of mammalian cell culturing techniques including capacity for monoclonal anti-body production, the stage was set for a productive era of discovery of human cancer associated antigens, including CA 125 for ovarian cancer. Recognition of the role of tumor promoters and suppressors in cancer formation and the development of powerful new genetic techniques led to discovery of a number of genes up or downregulated in cancer. This in turn has allowed focus on their gene products as potential cancer markers. Most recently the devel- opment of precise and high throughput mass spectrography has shifted the focus to proteomic patterns rather than specific markers. These methods are well suited for the discovery of entirely new biomarkers since the technique begins with no assumptions about the disease model and allows for post-translational modifications to be detected.

Most of the biologic models leading to marker development have focused on cancer cell cultures and invasive disease. Thus, it is not surprising that many of the markers identified so far are indicative of cell death, tissue remodeling or invasion, inflammatory response elements, or systemic response markers. These types of markers would seem to be most appropriate in late stage disease as appears to be the case for most of the markers in Table 1. Perhaps, new paradigms will be necessary for detection of markers suited for detection of early stage disease. Methods better suited to 
detect trace concentrations associated with low tumor load, early genetic changes, or subtle changes related to tumor surveillance cells or the immune system are needed. With regard to the latter, we postulate that the largely unexplored area of auto-antibody formation to tumor products might prove useful for early stage disease. Another technical limitation is our ability to describe and quantitate glycosylation. Aberrant glycosylation has been known as a feature of cancer for many years, especially apparent for the epithelial sialomucins. Thus, advances may await newer techniques to quantitatively and qualitatively describe glycosylation and take this into consideration in marker assays.

Other limitations are also clearly apparent in reviewing the studies cited in Table 1, including those that affect the reliability of the sensitivity and specificity estimates. Precision of the estimates of sensitivity and specificity will be greater for larger versus smaller study populations; but the effect produced by the use of different populations in studies poses a problem less able to be predicted. Case groups may have different mixtures of disease stages and histologic types and grades that affect overall estimates of sensitivity. In addition, although some groups were explicit in stating that case specimens were limited to those collected pre-operatively, not all groups stated this allowing for the possibility that some specimens were collected in the immediate post-operative period. Few studies have used pre-diagnostic sera months or years before clinical diagnosis. Obviously, the types of controls selected will greatly influence the estimated specificity of a particular marker or combination of markers. Inclusion of surgical controls that have other gynecological conditions such as fibroids, endometriosis, or benign ovarian tumors will lead to lower specificity compared to non-surgical controls. In terms of relevance to general population screening, specificity estimates based upon healthy controls are best. Description of the case or controls populations sometimes did not include the proportions that were pre- and postmenopausal. CA 125 is known to vary by menopausal status and it is likely that a number of other markers will vary as well. A final limitation is that assay performance was seldom addressed in detail by including estimates of inter- and intra-assay coefficients of variation. Poor assay performance could seriously compromise the reproducibility of sensitivity and specificity estimates.

Conceding these limitations, we still had the goal in preparing this review to identify individual markers or combination of markers with the best performance. Individual serum markers measured by immunoassay that appeared to perform best (if we require a specificity of at least $90 \%$ and sensitivity of $75 \%$ or greater) included the following: CA 125, CA 15-3 and its variants, MAM-6, kallikrein 10, thrombin-antithrombin III, mesothelin, IAP, MCSF, SIL-2RA, and TPA. Combinations of markers achieving these objectives include CA 125 in combination with HMFG1/2, in combination with TAG 72 and CA 15-3, or in combination with IAP, or haptoglobin alpha. Clearly, high specificity is demanded if expensive or invasive diagnostics tests are required to follow-up on a positive screening test; and the $90 \%$ specificity required above may not be good enough. Singling out some markers with specificities above $98 \%$ (while maintaining sensitivities of at least $60 \%$ ) revealed some of the following markers TAG-72, kallikrein 6 or 10, MMP-2, and Mesothelin. As a suggestion for future combinations to examine, it would be reasonable to combine one or more marker from each category in Table 1 in hopes that complementary markers could be identified to improve sensitivity while selecting additional markers which have excellent specificity. One of the most important characteristics needed for future ovarian cancer markers is high sensitivity at early stages.

Our belief that there may already be a very satisfactory set of markers that exist for ovarian cancer must be tempered by the likelihood that this panel may be positive for benign ovarian diseases and other cancers. Thus, follow-up for a positive test may require a battery of imaging studies. Imaging studies that reveal a complex ovarian mass will likely lead to surgery and in some cases will reveal a benign tumor. We would argue this should not be considered a failure of screening. A woman with a $10 \mathrm{~cm}$ complex ovarian tumor requires surgery not only because of the mass's potential to be cancerous but also because of its potential to undergo torsion or rupture producing a surgical emergency. A "positive panel" for ovarian cancer not associated with an obvious ovarian mass will require additional imaging or screening studies that are already recommended on a routine basis including mammogram, colonoscopy, or chest x-ray.

In conclusion, as the search for new markers for ovarian cancer continues, it is important to re-assess what has been already learned in the past three or four decades of previous research on ovarian cancer. Good and likely reliable markers already exist that simply need to be combined together in more convenient assay platforms. New research would be worthwhile and should focus on underdeveloped areas such as autoantibodies to cancer proteins or further descriptors of 
glycosylation. Mass spectrometry approaches may reveal complex patterns of cleavage products that provide unique cancer signatures; but there will still be a need for identifying these products to determine their role in cancer pathogenesis or progression. Since the focus of research has largely been on serum markers, attention should also be given to the urinary markers, which may be ideally suited to investigation using the mass spectrometric approaches.

\section{References}

[1] H. Abdel-Aleem, A. Ahmed, A.M. Sabra, M. Zakhari, M. Soliman and H. Hamed, Serum alpha L-fucosidase enzyme activity in ovarian and other female genital tract tumors, Int J Gynecol Obstet 55 (1996), 273-279.

[2] G.L. Adonkis, E. Paraskevaidis, S. Tsiga, K. Seferiadis and D.E. Lolis, A combined approach for the early detection of ovarian cancer in asymptomatic women, Eur J Obstet Gynecol Reprod Biol 65 (1996), 221-225.

[3] A. Anisowicz, G. Sotiropoulou, G. Stenman, S. Mok and R. Sager, A novel protease homolog differentially expressed in breast and ovarian cancer, Molec Med 2 (1996), 624-636.

[4] A.T. Baron, E.M. Cora, J.M. Lafky, C.H. Boardman, M.C. Buenafe, A. Rademaker, D. Liu, D.A. Fishman, K.C. Podratz and N.J. Maihle, Soluble epidermal growth factor receptor (sEGFR/sErbB1) as potential risk, screening, and diagnostic serum biomarker of epithelial ovarian cancer, Cancer Epidemiology, Biomarkers \& Prevention 12 (2003), 103-113.

[5] A.T. Baron, J.M. Lafky, C.H. Boardman, S. Balaubramaniam, V.J. Suman, K.C. Podratz and N.J. Maihle, Serum sErbB 1 and epidermal growth factor levels as tumor biomarkers in women with stage III or IV epithelial ovarian cancer, Cancer Epidemio Biomarkers Prev 8 (1999), 129-137.

[6] R.C. Bast, T.L. Klug, E. St. John, E. Jenison, J.M. Niloff, H. Lazarus, R.S. Berkowitz, T. Leavitt, C.T. Griffiths, L. Parker, V.R. Zurawski and R.C. Knapp, A radioimmunoassay using a monoclonal antibody to monitor the course of epithelial ovarian cancer, $N$ Engl J Med 309 (1983), 883-887.

[7] R.C. Bast, S. Knauf, A. Epenetos, B. Dhokia, L. Daly, M. Tanner, J. Soper, W. Creasman, S. Gall and R.C. Knapp, Coordinate elevation of serum markers in ovarian cancer but not in benign disease, Cancer 68 (1991), 1758-1763.

[8] G.J. Beattie, J.E. Roulston, D.M. Eccles, J.M. Richardson, J. Fisken and R.C.F. Leonard, Alpha-fucosidase as a marker of genetic deletion in ovarian carcinoma, Ann Clin Biochem 30 (1993), 207-208.

[9] A. Ben-Arie, Z. Hagay, H. Ben-Hur, M. Open and R. Dgani, Elevated serum alkaline phosphatase may enable early diagnosis of ovarian cancer, Eur J Obstet Gynecol 86 (1999), 69-71.

[10] M. Bhattacharya, S.K. Chatterjee and J.J. Barlow, UridineSdiphosphat-galacotse: glycoprotein galactosyl-transferase activity in the ovarian cancer patient, Cance Res 36 (1976), 2096-2101.

[11] H.G. Burger, P.J. Fuller, S. Chu, P. Mamers, A. Drummond, B. Susil, P. Neva and D.M. Robertson, The inhibins and ovarian cancer, Mol Cell Endocrinol 180(1-2) (2001), 145148 .
[12] M. Castelli, F. Battaglia, G. Scambia, P. Benedetti Panici, G.Ferrandina, A.M. Mileo, S. Mancuso and U. Ferrini, Immunosuppressive acidic protein and CA 125 levels in patients with ovarian cancer, Oncology 48 (1991), 13-17.

[13] C.H. Chien, C.C. Huang, Y.H. Lin, J. Shen and S.N. Chow, Detection of serum transforming growth factor-alpha in patients of primary epithelial ovdarian cancers by enzyme immunoassay, Gynecol Oncol 66 (1997), 405-410.

[14] L.A. Cole, Y.X. Wang, M. Elliott, M. Latif, J.T. Chambers, S.K. Chambers and P.E. Schwartz, Urinary human chorionic gonadotropin free beta-subunit and beta-core fragment: a new marker of gynecological cancers, Cancer Res 48 (1988), 1356-1360.

[15] L.A. Cole, P.E. Schwartz and Y.X. Wang, Urinary gonadotropin fragments in cancers of the female reproductive system. I. Sensitivity and specificity, comparison with other markers, Gynecol Oncol 31 (1988), 82-90.

[16] M. Den Ouden, J. Ubachs, J. Stoot and Versch, Thrombinantithrombin III and D-dimer plasma levels in patients with benign or malignant ovarian tumors, Scand J Clin Lab Invest 58 (1998), 555-560.

[17] H.W. De Bruijn, K.A. ten Hoor, H. Boonstra, J. Marrink, M. Krans and J.G. Aalders, Cancer-associated antigen CA 195 in patients with mucinous ovarian tumours: a comparative analysis with CEA, TATI, and CA 125 in serum specimens and cyst fluids, Tumour Biol 14 (1993), 105-115.

[18] B. Dhokia, P.A. Canney, D. Pectasides, A.J. Munro, M. Moore, P.M. Wilkinson, C. Self and A.A. Epenetos, A new immunoassay using monoclonal antibodies HMFG1 and HMFG2 together with an existing marker CA125 for the serological detection and management of epithelial ovarian cancer, Br J Cancer 54 (1986), 891-895.

[19] E.P. Diamandis, A. Okui, S. Mitsui, L.-Y. Luo, A. Soosaipillai, L. Grass, T. Nakamura, D.J.C. Howarth and N. Yamaguchi, Human Kallikrein 11: A new biomarker of prostate and ovarian carcinoma, Cancer Research 62 (2002), 295300 .

[20] E.P. Diamandis, G.M. Yousef, A.R. Soosaipillai and P. Bunting, Human Kallikrein 6 (zyme/protease M/neurosin): a new serum biomarker of ovarian carcinoma, Clin Biochem 33 (2000), 579-583.

[21] E.P. Diamandis, A. Scorilas, S. Fracchioli, M. van Gramberen, H. de Bruijn, Henrik, A. Soosaipillai, L. Grass, G.M. Yousef, U. Stenman, M. Massobrio, A.G. van der Zee, I. Vergote and D. Katsaros, Human kallikrein 6 (hK6): A new potential serum biomarker for diagnosis and prognosis of ovarian carcinoma, J Clin Oncol 21 (2003), 1035-1043.

[22] S.M. Ellerbroek, D.A. Fishman, A.S. Kearns, L.M. Bafetti and M.S. Stack, Ovarian carcinoma regulation of matrix metalloproteinase- 2 and membrane type 1 matrix metalloproteinase through beta 1 integrin, Cancer Res 59 (1999), 1635-1641.

[23] M.J.A. Engelen, H.W.A. de Bruijn, H. Hollema, K.A. ten Hoor, P.H.B. Willemse, J.G. Aalder and A.G.J. van der Zee, Serum CA 125, carcinoembryonic antigen, and CA 19-9 as tumor markers in borderline ovarian tumors, Gynecol Oncol 78 (2000), 16-20.

[24] H. Feng, Ghazizadeh, H. Konishi and T. Araki, Expression of MUC1 and MUC2 gene products in human ovarian carcinomas, Jpn J Clin Oncol 32 (2002), 525-529.

[25] X. Filella, R. Molina, J. Jo, J.L. Bedini, J. Joseph and A.M. Ballesta, Tumor associated glycoprotein-72 (TAG-72) levels in patients with non-malignant and malignant disease, Bull Cancer 79 (1992), 271-277. 
[26] D.A. Fishman, Y. Liu, S.M. Ellerbroek and M.S. Stack, Lysophosphatidic acid promotes matrix metalloproteinas (MMP) activation and MMP-dependent invasion in ovarian cancer cells, Cancer Res 61 (2001), 3194-3199.

[27] J. Fisken, J.E. Roulston, C. Sturgeon, R.A. Badley, I. Jonrup, L. Aspinall and R.C.F. Leonard, The value of the human milk fat globule membrane antigen HMFG2 in epithelial ovarian cancer monitoring: comparison with CA125, Br J Cancer 67 (1993), 1065-1070.

[28] A.E. Frias, H. Li, G.L. Keeney, K.C. Podratz and T.K. Woodruff, Preoperative serum level of inhibin A is an independent prognositc factor for the survival of postmenopausal women with epithelial ovarian carcinoma, Cancer 85 (1999), $465-471$.

[29] A. Gadducci, M. Ferdeghini, C. Prontera, L. Moretti, L. Pellagatta, R. Bianchi and P. Fioretti, CA 195: a new monoclonal antibody-defined Le ${ }^{\mathrm{a}}$ blood group-related tumor marker in patients with epithelial ovarian cancer, Journal of Nucl Biol Med 35 (1991), 33-37.

[30] A. Gadducci, M. Ferdeghini, F. Buttitta, A. Fanucchi, C. Annicchiarico, C. Prontera, G. Bevilacqua and A.R. Genazzani, Preoperative serum antibodies against the $\mathrm{p} 53$ protein in patients with ovarian and endometrial cancer, Anticancer Res 16(6B) (1996), 3519-3523.

[31] F. Guadagni, C. Marth, A.G. Zeimet, P. Ferroni, A. Spila, R. Abbolito, M. Roselli, J.W. Greiner and J. Schlom, Evaluation of tumor-associated glycoprotein-72 and CA125 serum markers in patients with gynecologic diseases, Am J Obstet Gynecol 171(5) (1994), 1183-1191.

[32] B.L. Harlow, N.S. Weiss and E. Holmes, Plasma AlphaL-Fucosidase activity and the risk of borderline epithelial ovarian tumors, Cancer Res 50 (1990), 4702-4703.

[33] T. Hastie and R. Tibshirani, Discrimnant analysis by Gaussian mixtures, Journal of the Royal Statistical Society Series B-Methodological 58(1) (1996), 155-176.

[34] L. Hefler, C. Tempfer, H. Heinzl, G. Haeusler, P. Steindl, C. Schneeberger, G. Gitsch and C. Kainz, M3/M21 serum levels in women with adnexal masses and inflammatory diseases, Int J Cancer 79 (1998), 434-438.

[35] L. Hefler, C. Tempfer, G. Hausler, H. Heinzl and C. Kainz, Cytokeratin tumor markers in ovarian carcinoma: tissue polypeptide specific antigen (TPS) and M3/M21, Wiener Klinische Wochenschrift 110(18) (1998), 635-641.

[36] I. Hellstrom, G. Goodman, J. Pullman, Y. Yang and K.E. Hellstrom, Overexpression of HER-2 in ovarian carcinomas, Cancer Research 61(6) (2001), 2420-2423.

[37] I. Hellstrom, J. Raycraft, M. Hayden-Ledbetter, J.A. Ledbetter, M. Schummer, M. McIntosh, C. Drescher, N. Urban and K.E. Hellstrom, The HE4 (WFDC2) protein is a biomarker for ovarian carcinoma, Cancer Res 63(13) (2003), 36953700 .

[38] D.J. Hetzel, C.R. Stanhope, B.P. o'Neill and V.A. Lennon, Gynecologic cancer in patients with subacute cerebellar degeneration predicted by anti-Purkinje cell antibodies an dlimited in metastatic volume, Mayo Clinic Proceedings 65(12) (1990), 1558-1563.

[39] J. Hilkens, V. Kroezen, J.M.G. Bonfrer, M. De Jong-Bakker and P.F. Bruning, MAM-6 antigen, a new serum marker for breast cancer monitoring, Cancer Res 46 (1986), 2582-2587.

[40] E.V. Hogdall, C.K. Hogdall, S. Tingulstad, B. Hagen, K. Nustad, F.-J. Xu and R.C. Bast, Predictive values of tumor markers tetranectin, OVX1, CASA, and CA125 in patients with a pelvic mass, Int J Cancer 89 (2000), 519-523.
[41] E.V. Hogdall, C.K. Hogdall, J. Blaakaer, N.H. Heegaard, E. Glud, L. Christensen, J.E. Bock, B. Norgaard-Pedersen, A. Wiik and S.K. Kjaer, P53 autoantibodies in sera from Danish ovarian cancer patients and their correlation with clinical data and prognosis, APMIS 110(7-8) (2002), 545-553.

[42] C.D. Hough, K.R. Cho, A.B. Zonderman, D.R. Schwartz and P.J. Morin, Coordinately up-regulated genes in ovarian cancer, Cancer Res 61(10) (2001), 3869-3876.

[43] C.D. Hough, C.A. Sherman-Baust, E.S. Pizer, F.J. Montz, D.D. IM, N.B. Rosenshein, G.J. Riggins and P.J. Morin, Large-scale serial analysis of gene expression reveals genes differentially expressed in ovarian cancer, Cancer Res $\mathbf{6 0}(22)$ (2000), 6281-6287.

[44] J.A. Hurteau, R.P. Woolas, I.J. Jacobs, D.C. Oram, C.C. Kurman, L.A. Rubin, D.L. Nelson, A. Berchuck, R.C. Bast $\mathrm{Jr}$ and G.B. Mills, Soluble interleukin-2 receptor alpha is elevated in sera of patients with benign ovarian neoplasms and epithelial ovarian cancer, Cancer 76 (1995), 1615-1620.

[45] T. Ind, R. Iles, J. Shepherd and T. Chard, Serum concentrations of cancer antigen 125, placental alkaline phosphatase, cancer-associated serum antigen and free beta human chorionic gonadotrophin as prognostic markers for epithelial ovarian cancer, Br J Obstet Gynecol 104 (1997), 1024-1029.

[46] M. Inoue, H. Ogawa, K. Nakanishi, O. Tanizawa, K. Karino and J. Endo, Clinical value of sialyl Tn antigen in patients with gynecologic tumors, Obstetrics \& Gynecology 75(6) (1990), 1032-1036.

[47] M. Inoue, M. Fujita, A. Nakazawa, H. Ogawa, O. Tanizawa, Sialyl-Tn and X.I. Silyl-Lewis, CA 19-9, CA 125, carinoembryonic antigen, and tissue polypeptide antigen in differentiating ovarian cancer from benigh tumors, Obstet Gynecol 79 (1992), 434-440.

[48] I.J. Jacobs, D.H. Oram and R.C. Bast, Strategies for improving the specificity of screening for ovarian cancer with tumor-associated antigens CA 125, CA 15-3, and TAG 72.3, Obstet Gynecol 80 (1992), 396-399.

[49] M. Kawai, N. Iida, S. Inagaki, H. Yamashita, H. Imaizumi, M. Kakihara and Y. Arii, Acute phase protein (Alpha 1 AT) as a tumor marker in patients with ovarian cancer, Gan No Rinsho 35(7) (1989), 799-803.

[50] J.H. Kim, S. Skates, T. Uede, K. Wong, J.O. Schorge, C.M. Feltmate, R.S. Berkowitz, D.W. Cramer and S.C. Mok, Osteopontin as a potential diagnostic biomarker for ovarian cancer, JAMA 287(13) (2002), 167-169.

[51] J. Kim, D. Herelyn and W. Kwong-kwok et al., Identification of Ep-CAM autoantibody in patients with ovarian cancer, Clinical Cancer Res 9 (2003), 4728-4791.

[52] S. Knauf, Clinical evaluation of ovarian tumor antigen NB/70K: monoclonal antibody assays for distinguishing ovarian cancer from other gynecological disease, Am J Obstet Gynecol 158 (1988), 1067-1072.

[53] J. Kodama, Y. Miyagi, N. Seki, K. Tokumo, M. Yoshinouchi, Y. Kobashi, H. Okuda and T. Kudo, Serum c-reactive protein as a prognostic factor in patients with epithelial ovarian cancer, European Journal of Obstetrics \& Gynecology and Reproductive Biology 82 (1999), 107-110.

[54] K. Kudoh, Y. Kikuchi, T. Kita, T. Tode, M. Takano, J. Hirata, Y. Mano, K. Yamamoto and I. Nagata, Preoperative determination of several serum tumor markers in patients with primary epithelial ovarian carcinoma, Gynecol Obstet Invest 47 (1999), 52-57.

[55] J.M. Lancaster, B.C. Blanchette, B. Calingaert, R. Whitaker, J. Schildkraut, J. Marks and A. Berchuck, High expression of tumor necrosis factor-related apoptosis-inducing ligand is 
associated with favorable ovarian cancer survival, Clinical Cancer Research 9(2) (2003), 762-767.

[56] L. Luo, D. Katsaros, A. Scorilas, S. Fracchioli, R. Piccinno, I.A. Rigaul de la Longrais, D.J.C. Howarth and E.P. Diamandis, Prognostic value of human kallikrein 10 expression in epithelia ovarian carcinoma, Clin Cancer Res 7 (2001), 2372-2379.

[57] L. Luo, P. Bunting, A. Scorilas and E.P. Diamandis, Human kallikrein 10: a novel tumor marker for ovarian cancer? Clinica Chimica Acta 306 (2001), 111-118.

[58] L. Luo, D. Katsaros, A. Scorolas, S. Fraccjop;o, R. Bellino, M. van Gramberen, H. de Bruijn, U. Stenman, M. Massobrio, A.G.J. van der Zee, I. Vergote and E.P. Diamandis, The serum concentration of human kallikrein 10 represents a novel biomarker for ovarian cancer diagnosis and prognosis, Cancer Res 63 (2003), 807-811.

[59] H. Meden, D. Marx, W. Rath, M. Kron, A. Fattahi-Meibodi, B. Hinney, W. Kul and A. Schauer, Overexpression of the oncogene c-erb B2 in primary ovarian cancer: evaluation of the prognositc value in a Cox proportional hazards multiple regression, Int J Gynecol Pathol 13(1) (1994), 45-53.

[60] U. Menon, S.C. Riley, J. Thomas, C. Bose, A. Dawnay, L.W. Evans, N.P. Groome and I.J. Jacobs, Serum inhibin, activin and follistatin in postmenopausal women with epithelial ovarian carcinoma, Br J Obstet Gynaecol 107 (2000), 1069-1074.

[61] U. Menon and I.J. Jacobs, Recent developments in ovarian cancer screening, Curr Opin Obstet Gynecol 12 (2000), 3942.

[62] S.C. Mok, J. Chao, S. Skates, K. Wong, G.K. Yiu, M.G. Muto, R.S. Berkowitz and D.W. Cramer, Prostasin, a potential serum marker for ovarian cancer: identification through microarray technology, J Natl Cancer Inst 93 (2001), 14581464.

[63] R. Molina, B. Ojeda, X. Filella, G. Borras, J. Jo, E. Mas, J.J. Lopez and A. Ballesta, A prospective study of tumor markers CA 125 and CA19.9 in patients with epithelial ovarian carcinomas, Tumor Biol 13 (1992), 278-286.

[64] J.W. Moll, S.C. Henzen-Logmans, T.A. Splinter, M.E. van der Burg and C.J. Vecht, Diagnostic value of anti-neuronal antibodies for paraneoplastic disorders of the nervous system, Journal of Neurology, Neurosurgery \& Psychiatry 53(11) (1990), 940-943.

[65] M.M. Moradi, L.F. Carson, B. Weinberg, A.F. Haney, L.B. Twiggs and S. Ramakrishnan, Serum and ascitic fluid levels of interleukin-1, interleukin-6, and tumor necrosis factoralpha in patients with ovarian epithelial cancer, Cancer 72 (1993), 2433-2440.

[66] M.A. Moses, D. Wiederschain, K.R. Loughlin, D. Zurakowski, C.C. Lamb and M.R. Freeman, Increased incidence of matrix metalloproteinases in urine of cancer patients, Cancer Research 58 (1998), 1395-1399.

[67] Y. Negishi, H. Iwabuchi, H. Sakunaga, M. Sakamoto, K. Okabe, H. Sato and G. Asano, Serum and tissue measurements of CA72-4 in ovarian cancer patients, Gynecologic Oncology 48(2) (Feb 1993), 148-154.

[68] Y. Nishida, K. Kohno, T. Kawamata, K. Morimitsu, M. Kuwano and I. Miyakawa, Increased cathepsin L levels in serum in some patients with ovarian cancer: comparison with CA125 and CA72-4, Gynecologic Oncology 56 (1995), 357-361.

[69] S. Nozawa, Y. Udagawa, H. Ohkura, Y. Negishi, K. Akiya, N. Inaba, H. Takamizawa, E. Kimura and Y. Terashima, Serum placental alkaline phosphatase (PLAP) in gynecologic ma- lignancies - with special reference to the combination of PLAP and CA54/61, Clinica Chimica Acta 186(2) (1990), 275-284.

[70] M.D. Oberst, M.D. Johnson, R.B. Dickson, C.Y. Lin, B. Singh, M. Stewart, A. Williams, A. al-Nafussi, J.F. Smyth, H. Gabra and G.C. Sellar, Expression of the serine protease matriptase and its inhibitor HAI-1 in epithelial ovarian cancer: correlation with clinical outcome and tumor clinicopathological parameters, Clinical Cancer Research 8(4) (April 2002), 1101-1107.

[71] O.J. Owens and R.E. Leake, Growth factor content in normal and benign ovarian tumours, Eur J Obstet Gynecol Reprod Biol 47(3) (1992), 223-228.

[72] O.J. Owens, C. Stewart, I. Brown and R.E. Leake, Epidermal growth factor receptors (EGFR) in human ovarian cancer, $\mathrm{Br}$ J Cancer 64(5) (1991), 907-910.

[73] E.F. Petricoin, A.M. Ardekani, B.A. Hitt, P.J. Levine, V.A. Fusaro, S.M. Steinberg, G.B. Mills, C. Simone, D.A. Fishman, E.C. Kohn and L.A. Liotta, Use of proteomic patterns in serum to identify ovarian cancer, Lancet 359 (2002), 572 577.

[74] E. Petru, B.U. Sevin, H.E. Averette, O.R. Koechli, J.P. Perras and S. Hilsenbeck, Comparison of three tumor markers CA 125, lipid-associated sialic acid (LSA), and NB/70 - in monitoring ovarian cancer, Gynecol Oncol 38 (1990), 181186.

[75] R. Punnonen, K. Teisala, T. Kuppala, B. Bennett and J. Punnonen, Cytokine production profiles in the peritoneal fluids of patients with malignant or benign gynecological tumors, Cancer 83(4) (1998), 788-796.

[76] D.M. Robertson, T. Stephenson, E. Pryusers, H.G. Burger, P. McCloud, A. Tsigos, N. Groome, P. Mamers, J. McNeilage, T. Jobling and D. Healy, Inhibins/activins as diagnostic markers for ovarian cancer, Molecular and Cellular Endocrinology 191 (2002), 97-103.

[77] L.D. Roman, L.I. Muderspach, A.F. Burnett and C.P. Morrow, Carcinoembryonic antigen in women with isolated pelvic masses. Clinical utility? Journal of Reproductive Medicine 43(5) (1998), 403-407.

[78] R.A. Sagarra, L.A. Andrade, E.Z. Martinez, G.A. Pintos, K.L. Syrjanen and S.F. Derchain, P53 and Bcl-2 as prognostic predictors in epithelial ovarian cancer, Int J Gynecol Cancer 12 (2002), 720-727.

[79] M. Sawada, Y. Okudaira, Y. Matsui and Y. Shimzu, Immunosuppressive acidic protein in patients with ovarian cancer, Cancer 52 (1983), 2081-2085.

[80] G. Scambia, P. Benedetti, G. Panici, L. Baiocchi, L. Perrone, S. Greggi, P. DiRoberto and S. Mancuso, CA 15-3 serum levels in ovarian cancer, Oncology 45 (1988), 263-267.

[81] D. Schneider, R. Halperin, R. Langer, I. Bukovsky and A. Herman, Peritoneal fluid lactate dehydrogenase in ovarian cancer, Gynecologic Oncology 66 (1997), 399-404.

[82] N. Scholler, N. Fu, Y. Yang, Z. Ye, G.E. Goodman, K.E. Hellstrom and I. Hellstrom, Soluble member(s) of the mesothe$\mathrm{lin} /$ megakaryocyte potentiating factor family are detectable in sera from patients with ovarian carcinoma, Proc Natl Acad Sci 96 (1999), 11531-11536.

[83] B. Schmalfeldt, D. Prechtel, K. Harting, K. Spathe, S. Rutke, E. Konik, R. Fridman, U. Berger, M. Schmitt, W. Kuhn and E. Lengyel, Increased expression of matrix metalloproteinases (MMP-2), MMP-9, and the urokinase-type plaminogen activator is associated with progression from benign to advanced ovarian cancer, Clin Cancer Res 7 (2001), 2396-2404. 
[84] P. Sedlaczek, I. Frydecka, M. Gabrys, A. van Dalen, R. Einarsson and A. Harlozinska, Comparative analsyis of CA 125, tissue polypeptide specific antigen, and soluble interleukin-2 receptor alpha levels in sera, cyst, and ascitic fluids from patients with ovarian carcinoma, Cancer 95 (2002), 1886-1893.

[85] H.S. Shvartsman, K.H. Lu, J. Lee, J. Lillie, M.T. Deavers, S. Clifford, J.K. Wolf, G.B. Mills, R.C. Bast, D.M. Gershenson and R. Schmandt, Overexpression of kallikrein 10 in epithelial ovarian carcinomas, Gynecol Oncol 90 (2003), 44-50.

[86] F. Sichel, V. Salaun, E. Bar, P. Gauduchon, J.-P. Malas, J. Goussard and J.-Y. Talaer, Biological markers and ovarian carcinomas: galactosyltransferase, CA 125, isoenzymes of amylase and alkaline phosphatase, Clinica Chimica Acta 227 (1994), 87-96.

[87] S.J. Skates, F. Xu, Y.H. Yu, K. Sjovall, N. Einhorn, Y. Chang, R.C. Bast and R.C. Knapp, Toward an optimal algorithm for ovarian cancer screening with longitudinal tumor markers, Cancer 76(10 Suppl) (1995), 2004-2010.

[88] M. Suzuki, I. Sekiguchi and T. Tamanda, Clinical evaluation of tumor-associated mucin-type glycoprotein CA 54/61 in ovarian cancers: comparison with CA 125, Obstet Gynecol 76 (1990), 422-427.

[89] M. Suzuki, H. Kobayaski, M. Ohwada, T. Terao and I. Sato, Macrophage colony-stimulating factor as a marker for malignant germ cell tumors of the ovary, Gynecol Oncol 68 (1998), 35-37.

[90] Y. Tamada, S. Iida, D. Aoki, S. Nozawa and T. Irimura, Carbohydrate epitopes and mucin expressed by 17 human ovarian carcinoma cell lines, Oncol Res 11 (1999), 233-241.

[91] K. Tamakoshi, F. Kikkawa, K. Shibata, K. Tomoda, N.H. Obata, F. Wakahara, Y. Tokuhashi, H. Ishikawa, M. Kawai and Y. Tomoda, Clinical value of CA125, CA19-9, CEA, CA72-4, and TPA in borderline ovarian tumor, Gynecol Oncol 62 (1996), 67-72.

[92] C. Tempfer, L. Hefler, G. Haeusler, G. Sliutz, E. Hanzal, A. Reinthaller and C.H. Kainz, Serum M3/M21 in ovarian cancer patients, British Journal of Cancer 76(10) (1997), 1387-1389.

[93] C. Temper, H. Zeisler, Sliutz, H. Guenther, E. Hanzal and C. Kainz, Serum evaluation of interleukin 6 in ovarian cancer patients, Gyn Oncol 66 (1997), 27-30.

[94] B. Tholander, A. Taube, A. Lindgren, O. Sjoberg, U. Stendahl, A. Kiviranta, K. Hallman, L. Holm, E. Weiner and L. Tamsen, Pretreatment serum levels of CA-125, carcinoembryonic antigen, tissue polypeptide antigen, and placental alkaline phospatase, in patients with ovarian carcinoma, borderline tumors, or benign adnexal masses: relevance for differential diagnosis, Gynecol Oncol 39 (1990), 16-25.

[95] K. Toftager-Larsen, U. Hording, A. Dreisler, S. Daugaard, B. Lund, J. Bock, F. Lundvall, K. Frederiksen and B. NorgaardPedersen, CA-125, placental alkaline phospatase and tissue polypeptide antigen as preoperative serum markers in ovarian carcinoma, Gynecol Obstet Invest 33 (1992), 177-182.

[96] Y. Udagawa, D. Aoki, K. Ito, T. Uejima, M. Uemura and S. Nozawa, Clinical characteristics of a newly developed ovarian tumour marker, galactosyltransferase associated with tumor (GAT), European Journal of Cancer 34(4) (1998), 489-495.

[97] M.E. van der Burg, S.C. Henzen-Logmans, E.M. Berns, W.L. van Putten, J.G. Kli and J.A. Foekens, Expression of urokinase-type plasminogen activator (uPA) and its inhibitor
PAI-1 in benign, borderline, malignant primary and metastatic ovarian tumors, Int J Cancer 69(6) (1996), 475-479.

[98] C. Van Haaften-Day, P. Russell, C.M. Boyer, B.J. Kerns, J.R. Wiener, D.N. Jensen, R.C. Bast and N.F. Hacker, Expression of cell regulatory proteins in ovarian borderline tumors, Cancer 77(10) (1996), 2092-2098.

[99] R.H. Verheijen, S. von Mensdorff-Pouilly, G.J. van Kamp and P. Kenemans, CA 125: fundamental and clinical aspects, Seminars in Cancer Biology 9 (1999), 117-124.

[100] M.C. Wang, L.A. Valenzuela, G.P. Murphy and T.M. Chu, Purification of a human prostate specific antigen, Journal of Urology 167(3) (2002), 1226-1230.

[101] R.P. Woolas, F. Xu, I.J. Jacobs, Y. Yu, L. Daly, ClarkePearson, D.H. Oram and R.C. Bast, Elevation of multiple serum markers in patients with stage I ovarian cancer, JNCI 85 (1993), 1748-1751.

[102] R.P. Woolas, M.R. Conaway, F. Xu, I.J. Jacobs, Y. Yu, L. Daly, A. Prys Davies, K. O'Briant, A. Berchuck, J.T. Soper, D.L. Clarke-Pearson, G. Rodriguez, D.H. Oram and R.C. Bast, Combinations of multiple serum markers are superior to individual assays for discriminating malignant from benign pelvic masses, Gynecologic Oncology 59 (1995), 111-116.

[103] F.-J. Xu, S. Ramakrishnan, L. Daly, J.T. Soper, A. Berchuck, D. Clarke-Pearson and R.C. Bast, Increased serum levels of macrophage colony-stimulating factor in ovarian cancer, $A m$ J Obstet Gynecol 165 (1991), 1356-1362.

[104] F.-J. Xu, Y.-H. Yu, L. Daly, K. DeSombre, L. Anselmino, G.M. Hass, A. Berchuck, J.T. Soper, D.L. Clarke-Pearson, C. Boyer, L.J. Layfield and R.C. Bast, OVX1 radioimmunoassay complements CA-125 for predicting the presence of residual ovarian carcinoma at second-look surgical surveillance procedures, J Clin Oncol 11 (1993), 1506-1510.

[105] K. Yamashita, H. Hayashi, K. Mure, M. Ishikawa and T. Shimizu, Serum immunosuppressive substance in patients with gynecologic malignancies and in pregnant women, $C a n-$ cer 57 (1986), 69-74.

[106] B. Ye, D.W. Cramer, S.J. Skates, S.P. Gygi, V. Pratomo, L. Fu, N.K. Horick, L.J. Licklider, J.O. Schorge, R.S. Berkowitz and S.C. Mok, Haptoglobin-a subunit as potential serum biomarker in ovarian cancer: Identification and characterization using proteomic profiling and mass spectrometry, Clinical Cancer Research 9 (2003), 2904-2911.

[107] B. Ye, H.F. Rosenberg, L. Fu, S. Skates, R.S. Berkowitz, S.C. Mok and D. Cramer, Identification and validation of Eosinophil-derived neurotoxin as a candidate urinary biomarker for early stage of ovarian cancer by SELDI-MS profiling. AACR Proceedings of 94th Annual Meeting Cancer Research Vol 44, Washington DC, p 1366, Cancer Research 2003.

[108] B.W. Yin and K.O. Lloyd, Molecular cloning of the CA125 ovarian cancer antigen, J Biolog Chem 276 (2001), 2737127375.

[109] G.M. Yousef and E.P. Diamondis, Kallikreins, steroid hormones, and ovarian cancer: Is there a link? Minerva Endocrinolo 27 (2002), 157-166.

[110] G.M. Yousef and E.P. Diamandis, Expanded human tissue kallikrein family - A novel panel of cancer biomarkers, $T u$ mor Biol 23 (2002), 185-192.

[111] A.G. Zeimet, F. Guadagni, C. Marth, T. Amato, E. MullerHolzner, O. Huter, G. Daxenbichler and O. Dapunt, Vaue of the TAG-72 (CA72-4) tumor marker in primary diagnosis of ovarian carcinoma. A comparison with the established CA125 marker, Geburtshilfe und Frauenheilkunde 55 (1995), 195-199. 
[112] V.R. Zurawski, K. Sjovall, D.A. Schoenfeld, S.F. Broderick, P. Hall, R.C. Bast, G. Eklund, B. Mattsson, R.J. Connor, P.C. Prorok, R.C. Knapp and N. Einhorn, Prospective evaluation of serum CA 125 levels in a normal population, phase I: specificities of single and serial determinations in testing for ovarian cancer, Gynecol Oncol 36 (1990), 299-305.

[113] I.J. Jacobs, S.J. Skates, N. MacDonald, U. Menon, A.N. Rosenthal, A.P. Davies, R. Woolas, A.R. Jeyarajah, K. Sibley, D.G. Lowe, D.H. Oram, Screening for ovarian cancer: a pilot randomised controlled trial, Lancet 353 (1999), 1207-1210.

[114] Y. Xu, Z. Shen, D.W. Wiper, M. Wu, R. Morton, P. Elson, A. Kennedy, W. Alexander, J. Belinson, M. Markman, G. Casey, Lysophosphatidic acid as a potential biomarker for ovarian cancer and other gynecologic cancers, JAMA 280 (1998), 719-723.

[115] A. Kuesel, T. Kroft, M. Prefontaine, I.C.P. Smith, Lipoprotein(a) and CA125 levels in the plasma of patients with benign and malignant ovarian disease, Int J Cancer 52 (1992), 341-346
[116] C. Van Haaften-Day, Y. Shen, F. Xu, Y. Yu, A. Berchuck, L.J. Havrilesky, H.W.A. de Bruijn, A.G.J. van der Zee, R.C. Bast, N.F. Hacker, OVX1, macrophage-colony stimulating factor, and CA-125-II as tumor markers for epithelial ovarian carcinoma, Cancer 92 (2001), 2837-2844.

[117] M.A. McGuckin, G.T. Layton, M.J. Bailey, T. Hurst, S.K. Khoo, B.G. Ward, Evaluation of two new assays for tumorassociated antigens, CASA and OSA, found in the serum of patients with epithelial ovarian carcinoma - comparison with CA125, Gynecol Oncol 37 (1990), 165-171.

[118] Y. Lin, S. Chow, C. Chen, R. Chen, S. Huang, G. Huang, Evaluation of immunosuppresive acidic protein in human ovarian cancer, J Formos Med Assoc 93 (1994), 776-780.

[119] Y. Shimzu, E. Akagaki, K. Hirota, M. Kono, S. Miura, Y. Okudaira, K. Kurachi, Significance of immunosuppressive acidic protein in the diagnosis and follow-up of patients with ovarian cancer, in particular, as a marker for chemotherapeutic effects, Nippon Sanka Fujinka Gakkai Zasshi 38 (1986), $554-560$ 


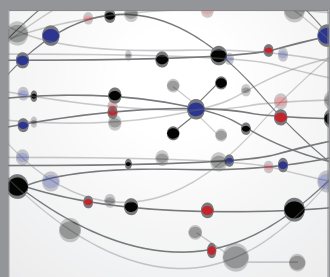

The Scientific World Journal
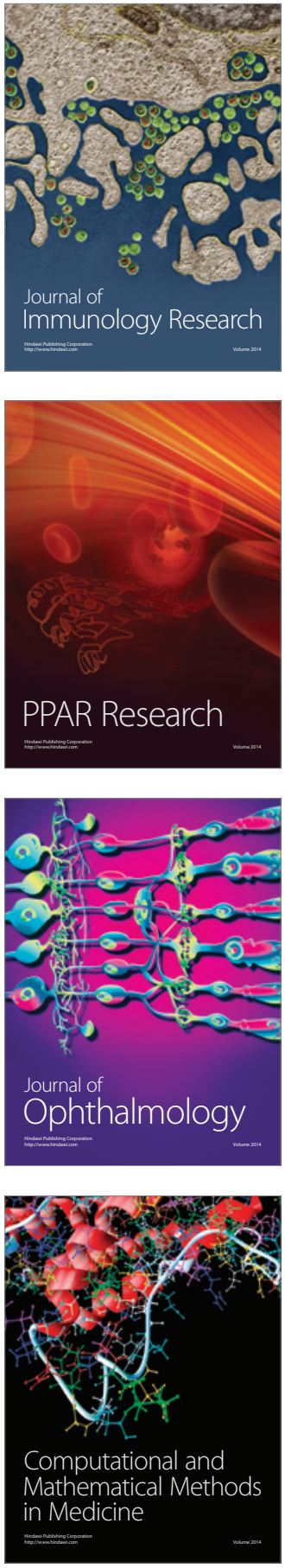

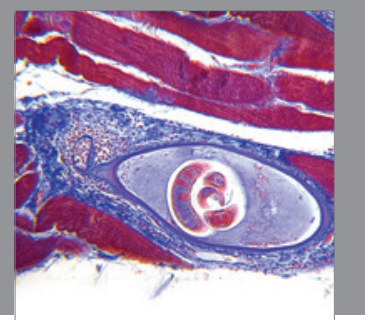

Gastroenterology

Research and Practice
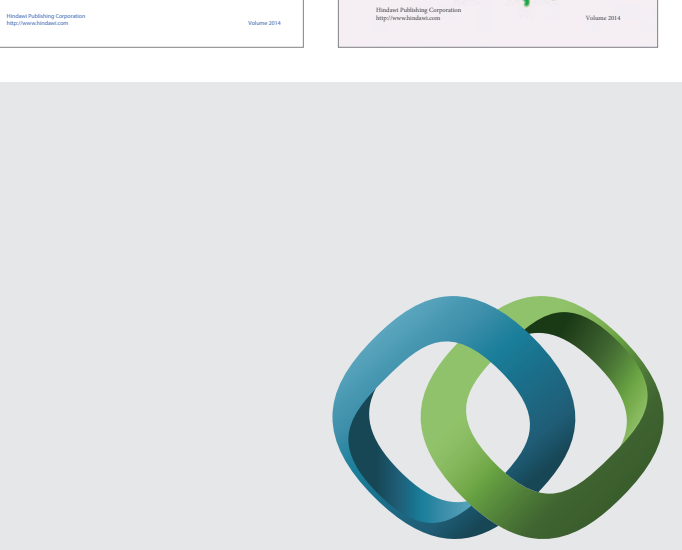

\section{Hindawi}

Submit your manuscripts at

http://www.hindawi.com
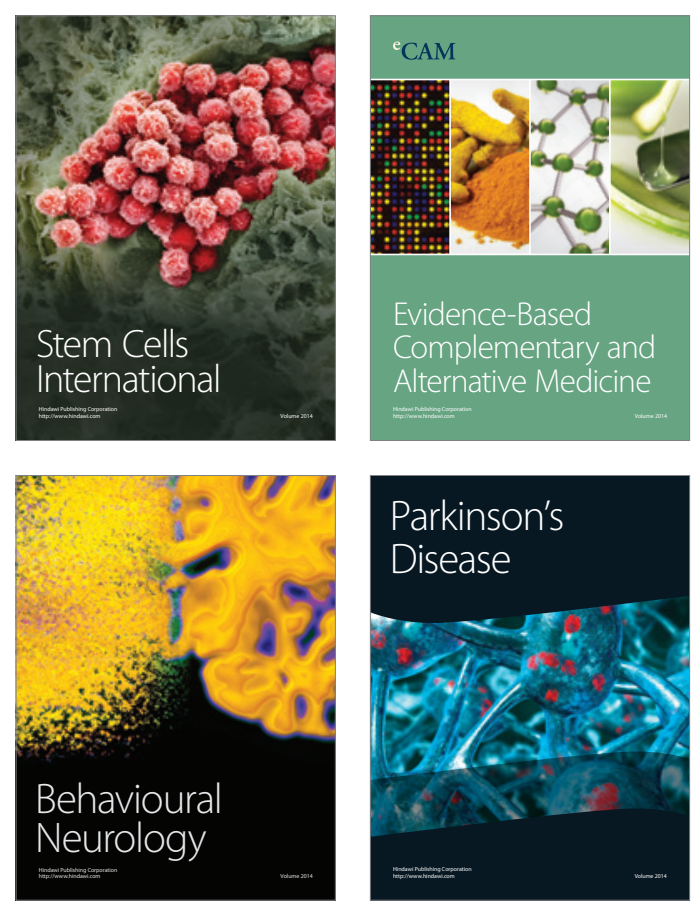

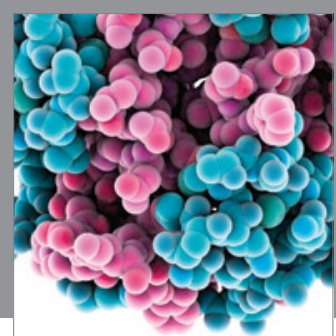

Journal of
Diabetes Research

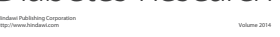

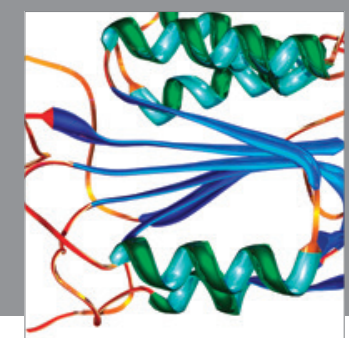

Disease Markers
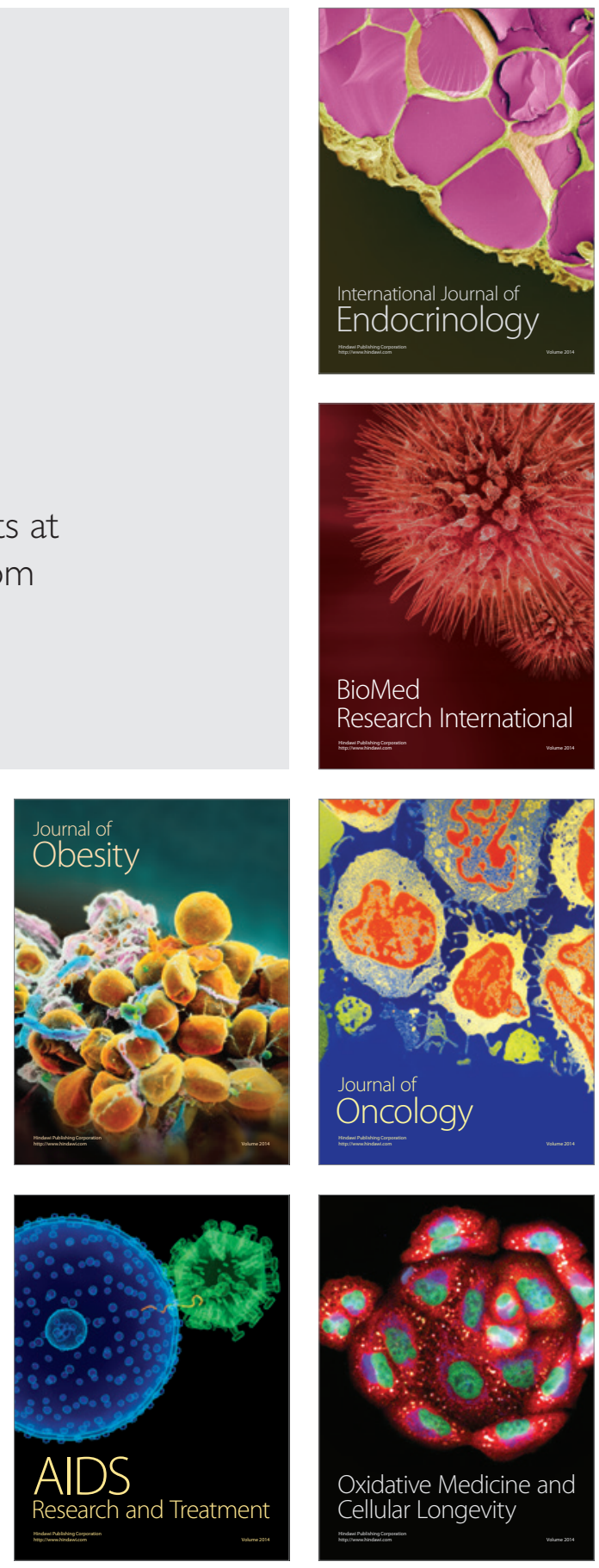